Received Date : 17-Feb-2016

Revised Date : 22-Sep-2016

Accepted Date : 02-Oct-2016

Article type : Original Article

\title{
IMPACT OF VOLCANISM ON THE SEDIMENTARY RECORD OF THE NEUQUÉN RIFT BASIN, ARGENTINA: TOWARDS A CAUSE AND EFFECT MODEL
}

Leandro D’Elia ${ }^{1}$; Joan Martí ${ }^{2}$ Martín Muravchik ${ }^{3}$; Andrés Bilmes ${ }^{4}$ and Juan R. Franzese ${ }^{1}$

${ }^{1}$ Centro de Investigaciones Geológicas (CIG) - CONICET, Universidad Nacional de La Plata, Diagonal $113 N^{\circ} 275$, La Plata B1904DPK, Argentina

2 Instituto de Ciencias de la Tierra "Jaume Almera", Consejo Superior de Investigaciones Científicas, Barcelona 08028, Spain

${ }^{3}$ Department of Earth Science, University of Bergen, Allégaten 41, N-5007, Bergen, Norway

${ }^{4}$ Instituto de Geología y Paleontología (CONICET-CENPAT), Boulevard Almirante Brown 2915, Puerto Madryn U9120ACD, Argentina

Corresponding author: Idelia@cig.museo.unlp.edu.ar

\section{ABSTRACT}

The analysis of volcano-sedimentary infill in sedimentary basins constitutes a challenge for basin analysis and hydrocarbon exploration worldwide. In order to understand the contribution of volcanism to the sedimentary record in rift basins, we study the Jurassic effusive-explosive volcanic infill of an inverted extensional depocentre at the Neuquén Basin, Argentina. A cause and effect model that evaluates the relationship between volcanism and sedimentation was devised to develop a conceptual model for the tectono-stratigraphic evolution of this volcanic rift basin. We show how the variations in the volcanism, coupled with the activity of extensional faults, determined the types of volcanic edifices (i.e., composite volcanoes, graben-calderas, and lava fields). Volcanic edifices controlled the stacking patterns of the volcanic units as well as sedimentary systems. The landform of the volcanic edifices, as well as the styles and scales of the eruptions governed the sedimentary input to the basin, setting the main variables of the sedimentary systems, such as provenance, grain size, transport and deposition and geometry. As a result, the contrasting volcaniclastic input, from

This article has been accepted for publication and undergone full peer review but has not been through the copyediting, typesetting, pagination and proofreading process, which may lead to differences between this version and the Version of Record. Please cite this article as doi: $10.1111 /$ bre. 12222

This article is protected by copyright. All rights reserved. 
higher volcaniclastic input to lower volcaniclastic input, associated with different subsidence patterns, determined the high-resolution syn-rift infill patterns of the extensional depocentre. The cause and effect model presented in this study isolates the variables of the volcanic environments that control the sedimentary scenarios. We suggest that, by adjusting the first order input parameters of the model, these cause and effect scenarios could be adapted to similar rift basins, in order to establish predictive facies models with stratigraphic controls, and the impact of volcanism on their stratigraphic records.

\section{INTRODUCTION}

The development of volcanic activity synchronous with some of the evolutionary stages of rift basins (e.g., East African Rift, South Atlantic basins, Red Sea Basin, the Mesozoic Western Gondwana basins; Morley, 1999; Ziegler \& Cloetingh, 2004; Chorowicz, 2005; Bosworth et al., 2005; Ramos, 2009; Ebinger \& Scholz, 2012) and extensional intra-arc basins (e.g., Intra-arc Taupo Volcanic Zone; Wilson et al., 2009; Rowland et al., 2010; Downs et al., 2015) is a widely recognized phenomenon. However, most tectono-stratigraphic works on extensional basins that addressed high-resolution sedimentary models, were performed on successions with null concomitant volcanism (e.g., Leeder \& Gawthorpe, 1987; Schlische, 1991, 1992; Schlische \& Anders, 1996; Leeder et al., 1996; Ravnås \& Steel, 1998; Gawthorpe \& Leeder, 2000). The mainstreams of research that took into account volcanic rift successions were focused on stratigraphic and chronostratigraphic schemes (e.g., Baker \& Mitchell, 1967; Baker, 1986; Ebinger et al., 1989; Skilling, 1993; Moore \& Kokelaar, 1997; D’Elia \& Martí, 2013; Chambefort et al., 2014, Downs et al., 2015) or the relationships between tectonic, magmatic and volcanic processes, such as the relation between tectonic structures and the magmatic system, the types and rate of subsidence (i.e., tectonic or volcano-tectonic subsidence), and what controls the development of different volcanic edifices (e.g., composite volcanoes and calderas) and their magmatic plumbing systems (e.g., Ebinger et al., 1989; Martí, 1991; Skilling, 1993; Moore \& Kokelaar, 1997, 1998; Ebinger \& Casey, 2001; Spink et al., 2005; Wolfenden et al., 2005; Aguirre-Díaz et al., 2008; Rowland et al., 2010; Ferguson et al., 2010; Ebinger \& Scholz, 2012; Acocella, 2014). Together, these studies illustrate fundamental feedbacks between tectonic, magmatic and volcanic process in rift basins, and show how related basin subsidence affects sedimentary processes. However, they do not consider how the construction of volcanic edifices that form a continuum with sedimentary scenarios, as well as variations in the style, volume, and frequency of volcanism, affect the highresolution architecture of the rift basins. Although, the high potential for hydrocarbon exploration in volcanic and associated sedimentary rocks in marine and continental basin infills has recently been asserted (e.g., Hinterwimmer, 2002; Sruoga et al., 2004; Lenhardt \& Götz, 2011; Caineng et al., 
2013), and reservoir rocks in volcano-sedimentary successions have been reported in several sedimentary basins worldwide (Mathisen \& McPherson, 1991; Pángaro et al., 2002; Sruoga et al., 2004; Feng, 2008; Legarreta et al., 2008; Pángaro et al., 2009), the difficulty in establishing predictable facies models (Németh \& Martin, 2009) and the large variation in the petrophysical properties of volcanic and volcaniclastic successions (Mathisen \& McPherson, 1991; Sruoga et al., 2004) have contributed to the lack of information on the relationship between volcanism and sedimentation with regard to basin studies, in particular in extensional basins.

Volcanic activity has an effect of great magnitude on basins and sedimentary systems. In the long term, as well as the short term, volcanism affects the main variables of a sedimentary basin, which are taken into account in basin analysis, such as the uplift, subsidence and supply rate of sediments (Allen \& Allen, 2013). The nature of volcanic edifices, whether as constructional features (e.g., composite volcanoes) or substrate collapse (e.g., caldera), affects and superimposes the tectonic relief (Thouret, 1999) and subsidence (Van Wyk de Vries \& Merle, 1996; Moore \& Kokelaar, $1997,1998)$ within the sedimentary basins. In the short term, the influence of volcanic activity on sedimentary basins is substantial due to the volume of the supplied material and its rate of supply, which is generally orders of magnitude bigger than those of non-volcanic sedimentary systems (Thouret, 1999; Mathisen \& McPherson, 1991; Fisher \& Smith, 1991; Manville et al., 2009). For instance, the average present-day discharge of the Brahmaputra River is $\sim 0.67 \mathrm{~km}^{3} / \mathrm{yr}$ (Goodbred \& Kuehl, 2000), whereas the 1991 eruption of Mount Pinatubo or the 2008 eruption of the Chaitén volcanoes delivered about $5-8 \mathrm{~km}^{3}$ in a few days (cf. Scott et al., 1996a, 1996b; Lara, 2009), causing the complete modification of the sedimentary environment (Hayes et al., 2002; Umazano et al., 2014). Volcanic products have a strong aggradational tendency (Smith, 1987, 1991; Haughton, 1993; Martina et al., 2006; Paredes et al., 2009), whether as positive topographic features (e.g., Palmer and Neall, 1991; Palmer et al., 1993; Karátson \& Németh, 2001; Zanchetta et al., 2004) or filling preexisting depressions (i.e., overfilled state; Busby \& Bassett, 2007; Muravchik et al., 2011). During volcanic eruptions, the depositional landscape may be modified in a matter of only hours or days (e.g., Cas \& Wright, 1987; Thouret, 1999; Davidson \& De Silva, 2000; Németh \& Martin, 2007). Such capacity to drastically modify the sedimentary conditions, as well as the basin configuration, leaves an unambiguous imprint in the stratigraphic record, which leads to the misunderstanding of the volcanic successions in the framework of basin analysis.

This article is protected by copyright. All rights reserved. 
The present study includes a volcano-tectono-stratigraphic analysis of the Lower Jurassic exposures of the Sañicó half-graben in the Neuquén Basin, Argentina. It focuses on how the coupled activity of volcanism and extensional tectonics determined not only the $4 \mathrm{D}$ evolution of the rift depocentre, but also, on how the external controls interacted to set the high-resolution architecture of different syn-rift stages. The combination of uplift and tectonic deformation during Andean orogeny, as well as the Quaternary fluvial incision, facilitates exposure of the whole hanging-wall and footwall stratigraphy in the rift basin, both along- and across-strike, and the identification of the tectonic structures. Detailed geochemical, petrographic, petrologic data, as well as a tectonostratigraphic model of this basin can be found in D'Elia et al. (2012a, 2012b); D'Elia and Martí (2013); and D'Elia et al. (2015). Here, we integrate this dataset with new observations to perform the following comprehensive sequenced analysis: i) analysis of genetically related lithofacies (grouped by unconformity) in order to determine the depositional processes/environments and the high resolution stratigraphy to volcanic and sedimentary counterparts; ii) identification of the main volcanic and tectonic variables that set each high-resolution stage; and iii) integrated analysis of the "counterparts" through a cause and effect model that identifies the volcanic variables that contributed to the control of the sedimentary scenarios. By comparing with other similar rift basins, the contributions of this work are not only expected to be of relevance in the field of academic research, but also in hydrocarbon exploration, as the understanding of the role of volcanism on sedimentary-volcanic rift basins may have significant impact on volcanic rift successions that may constitute important targets for the oil and gas industry.

\section{GEOLOGICAL SETTING}

The Neuquén Basin is located on the eastern side of the Andean margin in central Argentina, and more restrictedly in Chile, between $32^{\circ}$ and $40^{\circ} \mathrm{S}$ latitude (Fig. 1). The Neuquén Basin experienced a complex tectonic history that includes: (i) an initial extensional tectonic phase that developed in the palaeo-Pacific margin of Gondwana from the Late Triassic to the Early Jurassic; (ii) subduction-related thermal subsidence until the middle Cretaceous, in which punctuated episodes of localized inversion occurred; and (iii) a major basin inversion related to the Andean contractional tectonics, which occurred from the Late Cretaceous to the Neogene (Uliana \& Legarreta, 1993; Vergani et al., 1995; Legarreta \& Uliana, 1996; Franzese \& Spalletti, 2001; Howell et al., 2005).

The distribution of the basin fill can be divided into two distinctive regions: a western region, comprising the Andean Neuquén and Mendoza provinces, in which basin inversion caused the partial uplift and exposure of the basin infill (Fig. 1), and an eastern region, where most of the sedimentary record lies in the subsurface (e.g., Vergani et al., 1995; Howell et al., 2005). Surface and subsurface

This article is protected by copyright. All rights reserved. 
studies show that the rift segments are elongated troughs, 20 to $150 \mathrm{~km}$ long and 10 to $50 \mathrm{~km}$ wide, commonly composed of depocentres with half-graben geometries that display alternating polarity (Vergani et al., 1995; Cristallini et al., 2006). The initial half-graben depocentres were associated with profuse volcanic activity (Franzese \& Spalletti, 2001; D'Elia et al., 2012a) that generated thick subaerial volcanic successions (Precuyano Cycle; Gulisano et al., 1984). The syn-rift contains a large volume of lava flows and pyroclastic deposits (D'Elia et al., 2012a), associated with volcaniclastic and epiclastic sedimentary environments (Franzese et al., 2006, 2007; Muravchik et al., 2011; D’Elia et al., 2012b; Muravchik et al., 2014). This rift phase was followed by a diachronic Upper Triassic-Lower Jurassic regional marine transgression (Cuyano Cycle; Groeber, 1946) that flooded the Neuquén basin under the last syn-rift to post-rift stages (Vergani et al., 1995; D’Elia et al., 2015).

\section{TECTONO-STRATIGRAPHY OF THE NEUQUÉN BASIN}

The pre-rift units in the study area (Fig. 2) are formed by igneous-metamorphic rocks, including the Cushamen Formation the Mamil Choique Formation of upper Palaeozoic age (Varela et al., 1991). The syn-rift megasequence (Precuyano Cycle; Gulisano et al., 1984) in the southern part of the Neuquén Basin is composed of three sequences (Fig. 2) that were accommodated in different extensional depocentres during the rifting evolution (Fig. 3; D'Elia et al., 2015). The first syn-rift sequence corresponds to a thin succession of fluvial siliciclastic deposits of Upper Triassic age (i.e., Paso Flores Formation; Morel \& Ganuza, 2002), preserved in N-S-oriented depocentres (Figs. 2 and 3). The second syn-rift sequence in the study area comprises a thick Lower Jurassic (i.e., Sinemurian age; Stipanicic et al., 1968) succession of lava flows and ignimbrites along with sedimentary deposits, grouped into the Sañicó Formation (Fig. 2; Stipanicic et al., 1968). This unit was accommodated in two NE-SW-oriented half-grabens, such as the Sañicó and the Piedra del Águila extensional depocentres (Fig. 3). The last syn-rift sequence, which is transitional with the post-rift phase of the basin, corresponds to the lower-upper Pliensbachian marine succession (Damborenea \& Manceñido, 1993) of the Piedra Pintada Formation (Stipanicic et al., 1968; Stipanicic, 1969). Marine deposits consist of a 250-m-thick succession of massive to millimetre-scale laminated mudstones with ammonite and bivalve fossils, and plant remains. The boundary between the syn-rift and the transitional post-rift units is either a conformable surface or an angular unconformity, representing a short depositional hiatus (D'Elia et al., 2012b).

The Sañicó depocentre is a well-preserved uplifted rift depocentre of the Neuquén basin, where the complete volcanic syn-rift sequence can be analyzed. During the Miocene, the Sañicó depocentre, as part of the North Patagonian Andes, was affected by contractional tectonics (Bilmes

This article is protected by copyright. All rights reserved. 
et al., 2013; Ramos et al., 2014). Even though it experienced partial inversion and uplifting, its original geometry can still be clearly recognized by stratigraphic correlation of the syn-rift units, revealing an overall half-graben geometry (Figs. 3 and 4). The boundaries of the depocentre are presently exposed as NE-SW-trending basement-cored anticlines (Fig. 3c). The hanging-wall blocks are defined by mainly NE- and ENE-oriented extensional and partially inverted normal faults. These normal faults are spaced 0.1 to $3 \mathrm{~km}$ apart, ranging from 3 to $8 \mathrm{~km}$ in length, and show a predominant dip-slip sense of movement and a displacement ranging from tens to several hundred metres (Figs. 3 and 4; D'Elia et al., 2012b; D'Elia \& Martí, 2013). The syn-kinematic sequence of the Sañicó depocentre is the Sañicó Formation. It shows a large thickness change within the depocentre, with successions reaching a thickness of $1700 \mathrm{~m}$ thick at the NW margin of the depocentre, which contrasts with the 600- to 0-m-thick successions observed at its SE margin (Fig. 4D and 4E). Based on previous U-Pb SHRIMP geochronological data (Spalletti et al., 2010) and on the palaeontological analysis carried out with high-resolution ammonite biozonation in the lower marine deposits of the Piedra Pintada Formation (Damborenea \& Manceñido, 1993), the Sañicó Formation is constrained between $191.7 \pm 2.8 \mathrm{Ma}$ and $\sim 190.8 \pm 1.0 \mathrm{Ma}$ (International Chronostratigraphic Chart, 2015). Therefore, the syn-rift interval analyzed is constrained from the middle to upper Sinemurian, with a maximum depositional lapse of approximately 4.5 Myr.

\section{METHODOLOGY AND TERMINOLOGY}

Detailed geological mapping, and sedimentary and stratigraphic logging were performed in order to determine the lateral and vertical variations of the syn-rift units of the Sañicó depocentre (Fig. 4). Seventeen log sections were logged at 1:100 scale (Fig. 4). To address a volcano-tectono-stratigraphy analysis, the identification of unconformity-bounded assemblages of strata was performed, allowing the recognition of different relatively conformable successions of genetically related units deposited during distinct tectonic-volcanic events. Facies analysis of both volcanic and sedimentary units allowed the characterization of the main processes of transport and accumulation. Rock body geometry was assessed by analyzing photomosaics and fence diagrams of the exposures to identify bounding surfaces and stratal patterns. Facies associations were determined and used to establish the key volcanic and sedimentary elements involved in the accumulation of the studied units and to characterize the accumulation environment. The relative abundance of lava, pyroclastic and sedimentary rocks and their minimum volumes were estimated by weighting the thickness variations deduced from the stratigraphic logs and their areal correlations. Provenance analysis of conglomerate was performed in the field by counting 200 clasts along a square matrix adjusted according to the grain size of the deposits at each counting site. In order to provide a detailed

This article is protected by copyright. All rights reserved. 
quantification of the compositional variations observed, sample stations were arranged following a vertical trend along logs in the sedimentary sectors. Sandstone facies were sampled and provenance analysis was determined by point counting under microscope.

In the present work we use the term volcaniclastic as defined by White and Houghton (2006), to refer only to volcanic clasts directly related to volcanism, and not using it as a more general term applicable to all deposits containing clasts with a volcanic heritage (cf., Fisher, 1961). Thus, deposits of clasts resulting from weathering and erosion of previous volcanic rocks are named here epiclastic rocks/deposits. The term primary volcaniclastic rock (e.g., ignimbrite) is applied to every type of deposits resulting directly from a volcanic eruption (White \& Houghton, 2006), which are described using the grain size classification introduced by Fisher and Schmincke (1984), such as ash, tuff, tuff breccia. The deposits originated by secondary surface processes of transport and deposition, with either volcaniclast or epiclast provenance, are described using grain size classification of classic siliciclastic sedimentology (i.e., conglomerate, sandstone, siltstone).

Facies analysis allowed determination of facies models corresponding to different types of volcanic edifices. We use the definition of Németh and Kereszturi (2015) for "monogenetic volcano" to refer to a volcanic edifice with a small cumulative volume that has been built up by one or many discontinuous, small eruptions occurring over a short timescale, whereas the term "polygenetic volcano" is applied to a volcanic edifice with a large cumulative volume that has been built up by many discontinuous, small or large eruptions occurred in a longer timescale (ka to Ma). In this sense, monogenetic or polygenetic successions were defined according to 3D volcanic facies associations (volume) and the evaluation of the stacking patterns, taking into account the boundary strata or unconformities surfaces (time).

\section{SYN-RIFT SEQUENCE}

Based on the intra-depocentre discontinuity surfaces and stacking patterns of the Sañicó syn-rift, this syn-kinematic sequence was separated into three sections, which in turn correspond to three accumulation stages: the lower, middle and upper stages (Fig. 5; D'Elia et al., 2012b; D’Elia \& Martí, 2013). Volcanic rocks are volumetrically the most important units in the lower and middle stages, while they are less abundant in the upper stage of the syn-rift sequence (Fig. 4). Each stage is characterized by a particular volcanic environment, associated with contrasting sedimentary units.

This article is protected by copyright. All rights reserved. 


\section{Lower stage accumulation units}

The lower stage comprises units accumulated during the earliest syn-rift phases (Fig. 4). During this stage, syn-rift deposits show a clear wedge shape, limited by faults, with a maximum thickness of up to $1100 \mathrm{~m}$ (Fig. 4). Lower stage accumulation units were mainly preserved in the hanging-wall blocks in a highly compartmentalized depocentre. Lower stage rocks are characterized by lava units, which form up to $61 \%$ of the total volume of this phase (Fig. 4C), associated with volcaniclastic sediments and minor silicic pyroclastic deposits. All units are intruded by andesitic dykes, and silicic necks and cryptodomes (Fig. 4A). Although volcanic compositions vary from andesites to rhyodacites, andesitic lava successions constitute the dominant component.

Andesite lava units show particular thickness changes along and across the depocentre. Close to the depocentre boundary, at the footwall blocks, the volcanic products of this stage are characterized by andesitic lava flows up to $120 \mathrm{~m}$ thick, ranging from mainly sheet coherent andesitic lava flows to minor autobrecciated lavas (Figs. 6A and 6B). Dike swarms parallel to the border system faults occur, along with isolated plug- and dome-like intrusion bodies (Figs. 4A, 4A and 6E) associated with penetrative hydrothermal alteration. At the hanging wall, transverse to the faulted margins of the depocentre, lava facies occur as mainly coherent lava flows with sheet geometries of tens of metres thick. Towards the interior of the depocentre, lava facies gradually change to lenticular or tabular lava flows with abrupt lateral lithofacies changes, characterized by autoclastic carapace breccia facies consisting of slabby or rubbly oxidized blocks with a sparse interstitial matrix (Figs. 6C and $6 \mathrm{~F}$ ). The proportion of autobreccias/coherent lava facies increases from the boundary (where vents are located, see D'Elia \& Martí, 2013) towards the interior of the depocentre, developing into block-lava flows (Fig. 6B). Pyroclastic density current (PDC) deposits and conglomerate and breccia sedimentary deposits occur as isolated bodies intercalated in lava successions (Figs. 4 and 6D). PDC deposits appear either as thin decimetre-thick bodies or as large metre-thick lenticular bodies. They have an acid composition, a lapilli-tuff lithology with vitroclastic textures and a low grade of welding (Fig. 6D). Conglomerate and breccia sedimentary bodies, which show either tabular or lenticular geometries, prevail towards the interior of the depocentre and the top of the lower stage syn-rift succession (Fig. 4). Based on the analysis of the volcanic units, this stage was interpreted (Fig. 4A; D’Elia et al., 2012b; D’Elia \& Martí, 2013) as originating from volcano composite edifices located at the boundaries of the depocentre (Fig. 5A). From the vents to the distal position, lava flow units cannot be traced along great distances and show angular discordance. Facies change, combined with the abrupt lateral variation of lava units towards distal zones-which may indicate channel-confined, low aspect ratio lavas typical of steep sides common in volcanic edifices-, records the occurrence of

This article is protected by copyright. All rights reserved. 
central/proximal volcanic cone units to middle/distal volcanic cone units (see Hackett \& Houghton, 1989; Davidson \& De Silva, 2000).

Two sedimentary facies associations characterize the lower stage accumulation units: on the one hand, tabular volcaniclastic megabreccias and conglomerates and, on the other, channelized volcaniclastic conglomerates and sandstones (Fig. 7). The tabular volcaniclastic megabreccias and conglomerates are composed of unsorted megabreccias and poorly sorted conglomerates, forming laterally extensive bodies that can be up to $5 \mathrm{~km}$ long, $3 \mathrm{~km}$ wide and $200 \mathrm{~m}$ thick (Figs. 4, 7 and 8A). The megabreccias are clast- to matrix-supported massive deposits that compose successions up to $170 \mathrm{~m}$ thick. They are composed of angular to subangular andesitic clasts with sizes ranging from a few microns up to 20 metres in length. The fabric of the megabreccias varies from domains of jigsawfit texture to domains where the complete rotation and transport of clasts occurred (Figs. 9A and 9B). These characteristics, together with the composition of the clasts, suggest that the megabreccias derived from volcanic avalanche flows (Siebert, 1984; Glicken, 1991; Schneider \& Fisher, 1998; Ui et al. 2000; Clavero et al., 2002; Zanchetta et al., 2004; Bernard et al., 2009), in which fragmentation and dispersion mechanisms were originated by high-speed granular mass movements (Coussot \& Meunier, 1996) that behaved as dilatant fluids (Schneider \& Fisher, 1998). Conglomerate facies are poorly sorted, medium- to coarse-grained, sandy matrix-supported with andesitic clasts (Figs. 8B, 8D and 8E). They generally develop as lobate or tabular bodies 2 to $5 \mathrm{~m}$ thick and 50 to 150 $\mathrm{m}$ long at distal positions on top of the megabreccia facies (Fig. 8B). Their massive nature and the complete lack of tractional structures are interpreted as the result of non-cohesive debris-flow deposition (Shultz, 1984; Pierson et al., 1990; Coussot \& Meunier, 1996).

The channelized volcaniclastic conglomerate and sandstone facies association is constituted by horizontally stratified pebbly sandstones, massive to horizontally stratified conglomerates and, to a lesser extent, massive coarse-grained conglomerates and planar to trough cross-stratified sandstones (Figs. 7, 8C, 8F and 8G). It occurs as large channels and gully-fill bodies 10 to $50 \mathrm{~m}$ thick and 100 to $300 \mathrm{~m}$ wide that eroded previous syn-rift deposits (Fig. 7). The horizontally stratified pebbly sandstones appear as moderately sorted tabular bodies 5 to $20 \mathrm{~cm}$ thick with sharp or transitional lower boundaries and common normal grading (Fig. 8G), and are interpreted as sandy hyperconcentrated-flow deposits (Smith, 1986; Smith \& Lowe, 1991; Orton, 2002). The massive to horizontally stratified conglomerates are poorly sorted polymodal and clast-supported deposits, whose pebbles are aligned with their longest axes parallel to stratification (Fig. 8F). They occur as tabular or lenticular bodies decimetres to $1 \mathrm{~m}$ thick with transitional to sharp contacts. These

This article is protected by copyright. All rights reserved. 
features are indicative of gravelly hyperconcentrated-flow deposits (Smith, 1986; Smith \& Lowe, 1991; Orton, 2002). The massive coarse-grained conglomerates are poorly sorted with a sandy matrix, occurring in tabular bodies up to $5 \mathrm{~m}$ thick, which is indicative of non-cohesive debris-flow deposition (Shultz, 1984; Pierson et al., 1990; Coussot \& Meunier, 1996). The planar to trough crossstratified sandstones occur as moderately well sorted, thin $(1 \mathrm{~m}$ ) and narrow (up to $10 \mathrm{~m}$ ) bodies filling gullies eroded into the horizontally stratified pebbly sandstones (Fig. 8C). This relationship indicates overland floods associated with small shallow channels (see Blair, 2000). The channelized volcaniclastic conglomerates and sandstones show a conspicuous coarsening-upwards arrangement of facies from sandstones at the base towards conglomerates at the top. Among these deposits, the clast composition varies from andesitic lava clasts to polymictic clasts characterized by a mixture of provenances: andesitic lavas, pyroclastic materials and igneous-metamorphic clasts with an abundance that ranges from 5 to $30 \%$ (Fig. 7).

The sedimentary facies associations that developed in the lower stage syn-rift are the result of alluvial systems (Blair \& McPherson, 1994), reflecting different stages of degradation of volcanic edifices (Palmer \& Neall, 1991). The tabular volcaniclastic megabreccia and conglomerate facies association indicates gravitational collapses in proximal settings of high-relief andesitic edifices. Absence of deep incisions between volcanic debris avalanche and debris-flow deposits, together with their monomictic nature, suggests that the conglomerates resulted from reworking and resedimentation of the megabreccias (see Palmer et al., 1991; Bernard et al., 2009). The channelized volcaniclastic conglomerate and sandstone facies association corresponds to the deposition of highdensity flows with more mixed sources, comprising heterogeneous syn-rift components as well as pre-rift lithologies. This observation indicates the establishment of longer periods of erosion and degradation that favoured more integrated drainages affecting both volcanic and structural highs (see Palmer \& Neall, 1991; Zanchetta et al., 2004).

\section{Middle stage accumulation units}

In the middle stage, which is laterally continuous, a $400 \mathrm{~m}$ thick sequence of silicic PDC deposits occurs, constituting more than $85 \%$ of the volume of the middle stage succession (Fig. 4C). The PDC deposits represent the emplacement of two large-scale ignimbrite units, of around 20 kilometres long and hundreds meters thick, throughout the whole depocentre (Fig. 10A). The ignimbrite units were only identified inside the depocentre. They overlie the previous units throughout a sharp regional stratigraphic unconformity (Fig. 10B). Pyroclastic units are intercalated with volcaniclastic

This article is protected by copyright. All rights reserved. 
deposits and they are also intruded by domes associated with the internal faults of the depocentre (Figs. 4A, 4D and 4E).

The two rhyolitic/rhyodacite ignimbrites (Fig. 4E) are characterized by lapilli-tuff facies with massive or oriented fabrics, presenting moderate welding and particular post-depositional deuteric alteration (Fig. 10B). The two ignimbrite units are continuous along the interior of the depocentre and separated by thin tuffaceous volcaniclastic deposits (Fig. 4). These ignimbrites were only preserved inside the depocentre, showing facies and thickness variations. They are mostly developed in the interior zones of the depocentre and either gradually decrease in thickness, from hundreds of meters to tens of meters, or pinch out abruptly towards the depocentre margins, with important thickness changes related to extensional faults (Figs. 4 and 10A). Intra-formational breccia facies occur in the hanging-wall blocks of the interior faults, at the base of the ignimbrite units. These facies were interpreted by D'Elia and Martí (2013) as co-ignimbrite lag deposits, deposits often form during phases of caldera-collapse (i.e., Lipman, 1976) when caldera faulting occurs to accommodate a loss of mass (Figs. 4 and 10D). The facies changes and intrusive acid domes (Fig. 10E) are related to the faults of the depocentre. This allows the definition of the location of another magma plumbing system, which is also located at the boundary of the depocentre (Fig. 4; see D’Elia \& Martí, 2013). Therefore, ignimbrite units were associated with a significant volcano-tectonic subsidence episode, in which they overfilled the depocentre in a very short time, and are considered as representing a (half) graben-caldera stage (Fig. 5B; D’Elia \& Martí, 2013).

The sedimentary units that developed during the middle stage correspond to amalgamated volcaniclastic tabular bodies 1 to $50 \mathrm{~m}$ thick and up to $300 \mathrm{~m}$ in lateral extent (Figs. 4 and 11), which are intercalated between ignimbrite units (Figs. 4, 11A and 11B). They are composed of horizontally stratified pebbly tuffaceous sandstones, massive tuffaceous sandstones and, to a lesser extent, massive pumiceous breccias (Figs. 11B, 11C and 11D). The horizontally stratified pebbly tuffaceous sandstones are moderately sorted and form tabular bodies 5 to $30 \mathrm{~cm}$ thick with sharp contacts. The massive tuffaceous sandstones, which in some cases include some pumice lapilli fragments, are moderately sorted and clast-supported, deposited in tabular bodies 10 to $30 \mathrm{~cm}$ thick (Fig. 11D). The massive pumiceous breccias are fine-grained, clast-supported with polymodal sorting. They occur as tabular bodies 5 to $30 \mathrm{~cm}$ thick that in some cases develop normal to inverse-normal grading (Figs. 11B). The compositional analysis of these facies indicates an exclusive pyroclastic provenance with minimum transport (Fig. 9D). The sedimentary textures and structures observed suggest deposition from sandy/gravelly sheet flows in hyperconcentrated flow conditions and subordinate debris flows (Smith, 1986; Smith \& Lowe, 1991). Thus, these lithofacies suggest a close relationship between 
sediment gravity flow mechanisms of transport and deposition, and high rates of pyroclastic supply (Fisher \& Smith, 1991; Smith \& Lowe, 1991; Smith, 1991), which in conjunction with the absence of degradational cycles suggests a low-slope alluvial context in a high aggradational context with short depositional times (Smith, 1987; Smith, 1991; Fisher \& Smith, 1991).

\section{Upper stage accumulation units}

In the upper stage, andesitic lava flow successions associated with coarse- to fine-grained epiclastic units and carbonate rocks occur. All these units are asymmetrically distributed within the depocentre (Fig. 4). Deposits of this phase are only preserved inside the depocentre. The volume of the volcanic products within the syn-rift sequence decreases to $55 \%$ during this stage (Fig. 4C). The lower part of the upper stage syn-rift shows thickness changes across the interior faults and pinch out of the lava and sedimentary units. Towards the top, the lava and sedimentary units are laterally continuous, with subtle thickness changes across the interior faults. The andesite lava units occur as individual sheets that have been mapped along up to $7 \mathrm{~km}$ in length and are 5 to $30 \mathrm{~m}$ thick. Intercalated with the lava flows, thin sedimentary units are recorded. Most of the andesite sheets consist of a simple flow in which the tops and bottoms of individual lavas are remarkably regular and sub-parallel over distances of 5 to $7 \mathrm{~km}$ (Figs. 12A, 12B and C). The frequent occurrence of conformable, bedded sedimentary rocks between flows that show conspicuous vein structures and filled vesicles at the base of the flows indicates that the lavas were dominantly sub-horizontal and developed close to the depositional time of the sedimentation (Fig. 12D). Although lateral terminations of individual flows are locally exposed, highly discordant contacts are rare. Therefore, the upper stage volcanic units and sedimentary deposits were developed in a low gradient equilibrium (Fig. 5C; D'Elia et al., 2012b; D'Elia \& Martí, 2013). All of the above-mentioned features indicate the occurrence of andesitic lava fields aggrading in a low-relief environment, formed by the coalescence of lava flows erupted from several centres or fissures in the extensional depocentre (see Petterson et al., 1992).

The sedimentary elements emplaced during the upper stage (Figs. 4, 13 and 14A) consist of tabular and wedge-shaped bodies that are $50 \mathrm{~m}$ thick and up to $6 \mathrm{~km}$ long, grading from conglomerate-dominated facies in proximal areas to siltstones interbedded with limestones towards their distal reaches. The most proximal deposits to the depocentre margins display a distinctive vertical arrangement of the facies. At the base, they are characterized by poorly to moderately sorted, clast-supported fine to medium conglomerates forming tabular beds with irregular bases and a thickness of up to $1.5 \mathrm{~m}$ (Fig. 4). They are massive or stratified, either cross-stratified or horizontally stratified, with pebble long axes aligned parallel to the stratification. Moderately to well

This article is protected by copyright. All rights reserved. 
sorted clast-supported sandstones appear intercalated as cross-stratified lenticular and tabular beds with concave or sharp flat erosive bases. Towards the middle part of the succession, deposits become dominated by moderately sorted clast-supported, fine to medium conglomerates organized in large-scale cross-beds, dipping $21^{\circ}$ on average and grouped in 2- to 5-m-thick tabular packages (Figs. 13 and 14B and 14C). At the top of the proximal succession, the facies consists of massive and horizontally stratified, fine to medium conglomerate tabular bodies 0.3 to $1 \mathrm{~m}$ thick. To a lesser degree, horizontally stratified-laminated sandstones are found intercalated (Fig. 13). The compositional analysis reveals a polymictic volcanic provenance of the epiclastic deposits, (i.e., intermediate to acidic lavas and pyroclastic materials) with a low proportion of igneous-metamorphic clasts (Fig. 9E). The facies described above grade distally into stratified or massive fine-grained sandstones and reddish horizontally laminated siltstone beds 1 to $3 \mathrm{~cm}$ thick (Figs. $14 \mathrm{H}$ and 14l), interbedded with highly silicified 5 - to 20 - $\mathrm{cm}$-thick limestone beds. There is a very low preservation of primary sedimentary features in the carbonate facies. However, microbial lamination can be detected in some cases (Figs. 9F and 14J).

The lithologies described and their particular stacking pattern are consistent with those observed in coarse-grained delta systems (e.g., Postma, 1983; McPherson et al., 1987; Nemec, 1990; Backert et al., 2010). The basal part of the succession is thus interpreted to correspond to the toeset, with transitional characteristics between the coarser-grained foreset facies to the fine-grained prodelta facies. The absence of tractional structures in the conglomerate facies suggests their deposition from sediment gravity flow processes, whereas the stratified sandstone facies indicate underflow deposition caused mainly by low-density turbidity processes (e.g., Reading \& Collinson, 2002; Blair \& McPherson, 2008; Backert et al., 2010). The large-scale cross-bedded conglomerate packages occurring in the middle section represent different foreset progradation cycles, deposited by sediment gravity flows (Postma, 1983; Nemec, 1990; Backert et al., 2010). The massive and horizontally-stratified conglomerates at the top are interpreted as gravelly hyperconcentrated flow deposits (Smith, 1986; Smith \& Lowe, 1991) and the stratified and laminated sandstones as deposits from upper-flow-regime sheet floods (Blair \& McPherson, 1994) or very shallow stream flows associated with small channels (Blair, 2000). Both facies constitute the topset of this coarse-grained delta system. The overall predominance of sheet floods and hyperconcentrated flow deposits in the topset is characteristic of alluvial dominated environments (sensu McPherson et al., 1987; Blair \& McPherson, 1994).

This article is protected by copyright. All rights reserved. 
The horizontally-laminated siltstone facies represents deposition from suspension fallout or low-velocity flow and, together with the limestones, it constitutes the prodelta setting. The development of algal limestones requires aqueous environments of relatively low energy and moderate clastic input, under conditions of $\mathrm{CaCO}_{3}$ precipitation (e.g., Riding, 2000; Tucker, 2001; Dupraz et al., 2004). Their presence indicates water depths within the photic zone range $(\sim 30 \mathrm{~m})$ (e.g., Talbot \& Allen, 2002), which is also compatible with the scale of the foreset cycles (up to $4 \mathrm{~m}$ thick), indicating the shoal-water profile (Postma, 1990) of this coarse-grained delta system.

\section{DISCUSSION}

The analysis of the Sañicó half-graben infill succession carried out in this work, reveals how volcanism, in close relation with the tectonics, had different impacts on the stratigraphy and stacking patterns of that rift basin. In order to conceptualize and understand this volcano-sedimentary basin infill, we propose a cause and effect model (Fig. 15) in which the accurate evaluation of the volcanic activity (cause) makes it possible to understand the sedimentary systems that occurred (effect) in this rift basin. First, we will discuss the high-resolution facies models in the different contexts of the volcaniclastic input, taking into account the external controls on the infill, and then, we will discuss the cause and effect model and the implications for evaluating the impact of volcanism on the stratigraphic record of the rift basin.

\section{High-resolution facies model and external controls on the infill}

According to the syn-rift sequence analysis carried out in this study, the lower and middle stages will be analyzed within a high volcaniclastic input context, while the upper stage will be analyzed within a lower volcaniclastic input context (Fig. 15). From the perspective of the basin analysis, we define the volcaniclastic input as the supply rate of volcaniclastic materials to the basin, which is governed by the complex interaction of several parameters, such as the landform of the volcanic edifices, the eruption styles, and scales and frequencies of the volcanic eruptions (effusive or explosive), for which it exists a fundamental link between frequency and scale of the eruptions (Parfitt \& Wilson, 2008). It is important to remark that the style and scale of volcanic eruptions were obtained from volume estimates, dimensions and genetic analysis of the units (Fig. 4), whereas the chronologic framework was constrained from an allostratigraphic approach. Therefore, the analysis of genetic units and their boundary surfaces (discontinuities and surfaces) are assumed to have timestratigraphic significance. From high resolution stratigraphy point of view, the volcanic and sedimentary processes involve 2-3 orders of temporal magnitude less than the error margin of the radiometric dating. For instance, caldera cycles for systems worldwide are around 4-20 kyr to 300-

This article is protected by copyright. All rights reserved. 
$500 \mathrm{kyr}$ (Costa, 2008), the constructional phases of a ring plain of composite volcanoes may take around $1 \mathrm{kyr}$ (Palmer et al., 1993), and the eruptive frequencies of monogenetic volcanic fields are < 1 kyr (Németh \& Kereszturi, 2015), whereas the average error margin of the U-Pb SHRIMP radiometric data for the syn-rift in the Neuquén basin is from 2.8-0.26 Ma, on average $1 \mathrm{Ma}$ (e.g., Schiuma \& Llambías, 2008; Spalletti et al. 2010; Leanza et al., 2013).

High volcaniclastic input context

The volcanic successions associated with the lower stage of the Sañicó depocentre suggest that they were related to composite volcanoes. This type of volcanic edifice implies strongly aggradational features that can reach high altitudes (Thouret, 1999; Davidson \& De Silva, 2000; Németh \& Martin, 2007), developing steep slope gradients. Their growth in height and areal development reflected the high rate of production of volcanic material. The supply of volcaniclastic material in this first stage was mainly provided by the emplacement of blocky lava flows and pyroclastic deposits, but also the erosion and degradation of the composite volcanoes, resulting in thick, extensive volcaniclastic aprons (e.g., Palmer \& Neall, 1991; Palmer et al., 1991, 1993; Thouret, 1999; Orton, 2002; Németh \& Martin, 2007). The landscape resulting from the growth of composite volcanoes typically has a high gradient, with different processes affecting the stability of the volcano slopes. This condition is made evident by the development of volcanic avalanche flow deposits in the lower stage (Fig. 15), in which the distribution of the sedimentary facies and sedimentary units was also controlled by the geometry of the depocentre. The volcanic debris avalanche deposits are preserved in the hanging-wall fault of the depocentre, where andesitic lava flows, intrusive domes and associated volcaniclastic deposits prevail at the base (Figs. 4 and 7). The facies distribution suggests that the asymmetric shape of the volcanoes, caused by the tectonic structures and the polarity of the depocentre, controlled the occurrence and emplacement of the collapses. This situation agrees with analogue models and natural examples in which the close relationship between the structurally controlled asymmetry of the volcano and the position of the collapse can be observed (van Wyk de Vries \& Francis, 1997; Le Corvec \& Walter, 2009; Wooller et al., 2009). Subsequently, the short-lived resedimentation of the avalanche deposits originated debris flow deposits with andesitic provenance (see Bernard et al., 2009). Thus, the type of volcanism and depocentre position of the volcanic edifices controlled the main variables of the sedimentary environments. These variables include the distribution and dimension of the sedimentary environments, the high-gradient processes of transport and sedimentation, the coarse-grained size, and even the andesitic lithology of the sedimentary unit occurring in inter-eruptive stages (Fig. 15). Regarding the channelized volcaniclastic conglomerates and sandstones facies, large entrenchment channels associated with a passive infill suggest large

This article is protected by copyright. All rights reserved. 
degradational episodes of the volcanic relief (e.g., Palmer et al., 1993; Zanchetta et al., 2004). The predominantly andesitic composition suggests that flank lithology and local drainage networks controlled these units (Fig. 15). The drainage network was slightly integrated and dominated by the proximal conditions surrounding the volcanoes and, to a lesser extent, by epiclastic products originating from the erosion of the faulted pre-rift blocks. The vast dominance of andesitic lithoclasts among the deposits indicates that the degree of pre-rift exposure was very restricted. It is interpreted that this was not related to the small degree of uplift of faulted blocks, but to the aggrading nature of the composite volcanoes that grew over the pre-rift basement. The large amounts of sand-sized lava fragments originating from coherent or blocky lava flow units suggest that long-lived, inter-eruptive degradational processes took place (e.g., Brown \& Bell, 2007). In this context, the volcanic landscape, both during eruptive and inter-eruptive episodes, was the main provider of volcaniclastic material to the sedimentary environment with a predominance of gravity flows as the main mechanisms of transport and deposition of the sediments. In this case, the intereruptive lapses controlled the degree of erosive relief of the sedimentary units, as well as their grain size (i.e., the longer the lapse, the smaller the grain size of the deposits; Fig. 15).

During the middle stage, the Sañicó depocentre evolved into a graben-collapse caldera scenario (D'Elia \& Martí, 2013), produced by the emptying of a shallow magma chambers and the consequent collapse of the magma chamber roofs (e.g., Aguirre-Díaz et al., 2008). Collapse calderas provide the largest supply of volcaniclastic material in the shortest time (Lipman, 2000), saturating the capacity of the sedimentary agents to transport and redeposit the pyroclasts. In this particular case, the substantial synchronous subsidence undergone by the floor of the caldera trapped a big proportion of the supplied pyroclasts in the form of two main ignimbrites. In addition, the emplacement of these thick intra-caldera ignimbrites covered the previous topography and generated low-gradient environments (e.g., Németh \& Martin, 2007; Manville et al., 2009). Overall, the volcanic activity during the formation of a caldera dominates the depositional environment, and the sedimentary units found within the caldera fill tend to constitute extremely thin and laterally restricted deposits (Fig. 15). Therefore, in this context, the large explosive eruption events triggered a phase of ash/pumiceous-rich volcaniclastic syn-eruptive sedimentation. The low-gradient relief resulting from the nearly instantaneous massive and widespread emplacement in the depocentre of a large volume of pyroclastic material (see Muravchik et al., 2011) caused low-slope conditions that favoured the formation of volcaniclastic hyperconcentrated flows after their deposition (Fig. 15). A short syn-eruptive lapse set a non-integrated drainage network that drove the thin, limited lateral distribution of the sedimentary units, which-combined with a high aggradational rate-prevented

This article is protected by copyright. All rights reserved. 
the occurrence of major erosive surfaces and degradation cycles (see Fisher \& Smith, 1991; Fig. 15). A central point to the high-resolution stratigraphy of the middle stage is that, although the volume of extra-caldera ignimbrites can also be significant (Cas \& Wright, 1987), their preservation in the record of ancient extensional basins is interpreted to may be relatively small, as the areas external to the depocentre constitute the footwalls of the border fault systems and, as such, are subjected to uplift and erosion or even further tectonics (e.g., Martí., 1991). This observation is substantial when comparing the example studied here with younger and better preserved examples (e.g., Taupo Volcanic Zone; Rowland \& Sibson, 2001; Spink et al., 2005; Gravley et al., 2007; Wilson et al., 2009; Rowland et al., 2010; Allan et al., 2012; Chambefort et al., 2014; Downs et al., 2015).

During periods of high volcaniclastic input context (i.e., the lower and middle stages), a polygenetic, composite volcano and graben-caldera were formed in association with either extensional tectonic subsidence or volcano-tectonic (caldera collapse) subsidence, respectively (Martí, 1991; Moore \& Kokelaar, 1997, 1998; Fig. 15). The interpretation of the boundary surfaces between different volcanic and sedimentary units marks diverse orders of depositional hiatus, evidencing the complex superposition in space and time of these units. Differences in eruptive style, frequency, and volume of the eruptions from composite volcanoes and graben-calderas, determined different kind of "effects" on the sedimentary scenarios, in particular related to the grain sizes of the material supplied and their mechanisms of transport and deposition, and the sizes of the sedimentary units (Fig. 15). Thus, the high volume of pyroclastic materials mainly provided coarse silt to fine gravel particle sizes (Vessell \& Davis, 1981; Smith, 1991; Németh et al., 2009), and autoclastic lavas feed boulder and gravel size particles (see Hackett and Houghton, 1989; McPhie et al., 1993; Brown \& Bell, 2007), whereas the steep topography resulting from high aggradational volcanic edifices and/or the large volume of volcaniclastic material supplied to the depocentre led to mechanisms of transport and deposition dominated by gravity flow processes (Fig. 15). Regarding the scale of the sedimentary units, making a comparison between lower and upper middle units, the genetic interpretation of their boundary surface indicates that they have a positive correlation with the scale of the volume of the volcaniclastic input and a negative correlation with the lapse between the eruptions (Fig. 15).

Lower volcaniclastic input context

During the upper stage the input of volcanism to the sedimentation in the Sañicó depocentre decreased significantly. The most important change, with regards to the previous stages was the decrease or absence of eruptive-related volcaniclastic deposits, and the development of large-

This article is protected by copyright. All rights reserved. 
extended, coherent, tabular lava flows that blanket the depocentre in low relief conditions (evidenced by lava units with remarkably regular and sub-parallel contacts over long distances and lack of avalanches deposits). These lava flows were emplaced from different vents, thus reflecting more the existence of a monogenetic volcanic field than that of a composite volcano. As a consequence, there was a low volcaniclastic input to the depocentre. This is important to remark because the total eruptive volume of a whole volcanic field may be comparable with the total volume of eruptive products of a polygenetic composite volcano (Németh, 2010), although the impact of the volcaniclastic supply to the sedimentary environment is low, resulting in low potential of preservation in the sedimentary record (White, 1991). Monogenetic volcanic fields are composed of individual, short lived volcanoes that are commonly small in eruptive volume (see Walker, 2000; Németh \& Martin, 2007; Cabrera \& Caffe, 2009; Németh, 2010; Nishiki et al., 2011). The higher eruption frequency during this volcanic scenario could have been buffered in the record by the low volume of these eruptions and the change in vent locations over time, forming the typical dispersed patterns of volcanoes characteristic of volcanic fields (Németh \& Kereszturi, 2015). For this reason, the boundary surfaces between lava field products and stabilized delta-lacustrine environments, mark longer lapses than in higher volcanic input conditions. The paucity in which the lavas were spilt inside the depocentre allowed the drainage system to accommodate to the new topographic conditions over longer periods of time, enabling a better integrated drainage system to evolve in the area. The "effect" was a significant reduction of the influence of volcanism as an allocyclic control over the sedimentary systems, causing the high facies polarity-which is uncommon in volcanodominated sedimentary environments (Németh \& Martin, 2007)-, the polymictic provenance of the fan-delta facies, and the grain size (from gravel to siltstone), which were driven by weathering/erosion cycles of previous rocks. The widespread lava flow emplacement inside of the depocentre originated a new base level and low gradient conditions (adjusted to the landform of the lava field) and the relief was set by the tectonic processes. Therefore, the nature of the transport and depositional processes of the sedimentary environment were not different to those developed in non-volcanic rift depocentres (cf. Gawthorpe \& Leeder, 2000; Fig. 15). In this syn-rift stage the type and the evolution of this volcanic environment reduced the impact of volcanism on the sedimentary record with respect to other variables, such as the climate, tectonics or bedrock lithology (see Reading \& Level, 1996). This is evident in the development of limestones and stromatolitic facies in such starved depocentre conditions (e.g., Riding, 2000; Dupraz et al., 2004).

This article is protected by copyright. All rights reserved. 


\section{Towards a cause and effect model to evaluate impact of volcanism on the sedimentary record}

In recent decades, most of the studies addressing volcanic influence over sedimentary environments have focused on non-compartmentalized basins with a large areal distribution (e.g., foreland basin or linked rift basins; e.g., Smith, 1987, 1991; Haughton, 1993; Martina et al., 2006; Paredes et al., 2009) or non-restricted volcanic aprons (e.g., Walton \& Palmer, 1988; Palmer and Neall, 1991; Palmer et al., 1993; Karátson \& Németh, 2001; Zanchetta et al., 2004). Such studies have documented the controls of volcanic activity on sedimentation in either proximal areas or proximal to distal areas, based on provenance (Smith, 1988; Cole \& Ridgway, 1993; Haughton, 1993; Riggs et al., 1997), mechanisms of transport and deposition (Brantley \& Waitt, 1988; Walton \& Palmer, 1988; Bahk \& Chough, 1996), and aggradational versus degradational behaviour of the sedimentary units (Smith, 1987; Bahk \& Chough, 1996; Riggs et al., 1997). As a result of such significant works, several models have been proposed to understand the mechanism of transport and deposition, aggradational versus degradational behaviour, as well as the distribution and size of the volcano-related sedimentary environments. These models have been devised for several types of volcanoes and volcanic settings, as well as for several types of basins. However, these models may seem disconnected from each other, leading to a misinterpretation from the standpoint of basin analysis. The cause and effect model that we propose for the Sañicó basin, represents a "dynamic" scheme to explain the influence of the volcanic activity (cause) on the sedimentary regime of the basin (effect), for a specific accommodation space (i.e., tectonic or volcano-tectonic - caldera collapse- subsidence; Fig. 15). This evolution is similar to that observed in other extensional basins (Sierra Madre (Mexico), AguirreDíaz et al., 2008; Pyrenees (Spain), Martí, 1991; Glencoe (Scotland), Moore \& Kokelaar, 1998, Taupo Volcanic Zone; (New Zeland), Spink et al., 2005; Chambefort et al., 2014, Downs et al., 2015). In fact, many of the fundamental relationships established in this work, such as (i) coeval faulting and volcanism, (ii) monogenetic and polygenetic volcanoes associated with border fault systems, (iii) uplift and subsidence patterns locally controlled by explosive volcanic eruptions, and (iv) the development of calderas associated with regional tectonic structures, have been found in other rift systems (e.g. Southern Red Sea, Main Ethiopian Rift, Iceland; see Ebinger et al., 1989; Gudmundsson, 2000; Acocella et al., 2002, 2007; Spinks et al., 2005; Abebe et al., 2007; Ebinger and Casey, 2001; Wolfenden et al., 2004, 2005; Rowland et al., 2010; Ebinger \& Scholz, 2012). Nevertheless, it is not the aim of this work to propose a universal high resolution facies model for rift basins worldwide. Despite the similarities we may find, each case may have particular aspects that may imply important differences in the dynamics of each basin. The approach followed in this study may applied to other cases in order to facilitate obtaining a cause-effect model that could help to quantify the influence of volcanism on the sedimentary record of the basin. Essentially, the model presented in this study

This article is protected by copyright. All rights reserved. 
identifies the variables that control the influence of volcanic and tectonic activity on the sedimentary scenarios and the resulting stratigraphic record of a rift depocentre. Thus, adjusting the first order input parameters of the model this can be adapted to other similar rift basins, in order to establish predictive models on the impact of volcanism on their stratigraphic records.

\section{CONCLUSIONS}

Even though most rift basins may be associated with volcanism at some point of their evolution, stratigraphic analysis and high-resolution stratigraphy models do not always include volcanism as a major control over the sedimentary system. In such cases, the theoretical knowledge of the basin-fill architecture is mainly based on their 3D structural configuration, evolution of their drainage system, climate changes and variations of the base level or sea/lake level. Comparing with previous studies on volcanic rift basins where the focus is made on more specific aspects, the present work offers a multidisciplinary approach provides a holistic view of the interplay of tectonics, volcanism and sedimentation in the evolution of the Sañicó rift basin. We have considered volcanic and sedimentary units as a part of the continuum that took place in a particular space (i.e., accommodation space originated by tectonic or volcano-tectonic subsidence). Also, we have recognized depocentre-scale unconformities that group packages of volcanic and sedimentary units genetically associated with the different tectonic and volcanic events. Finally, we have established high-resolution facies models with accurate identification of the stratigraphic controls. The volcaniclastic input conditions, from lower input to higher volcaniclastic input, was determined by the complex interaction of several parameters of the volcanic scenario, such as the landform of the volcanic edifices, as well as the eruption styles, scales and frequencies of the volcanic eruptions, which, in turn, set the parameters that control the internal dynamics of sedimentary environments. In order to obtain a high-resolution stratigraphic model capable of evaluating the tectonostratigraphic evolution of the volcanic infill, we have proposed a cause and effect model assessing the relationship between volcanism and sedimentation, which can be easily generalized for other similar basins, in order to devise predictive models applied to the exploration and development of natural resources.

\section{ACKNOWLEDGEMENTS}

The authors would like to thank the inhabitants of the Sañicó area for their support and hospitality. Our thanks go to Julie Rowland, Károly Németh and an anonymous reviewer for their constructive and helpful reviews. This research was funded by the Agencia Nacional de Promoción Científica y Tecnológica, BID-PICT 2013-1888, the Consejo Nacional de Investigaciones Científicas y Técnicas

This article is protected by copyright. All rights reserved. 
(CONICET, Argentina), the Consejo Superior de Investigaciones Científicas (CSIC, Spain), and a MICINN grant CGL2010-22022-C02-02.

\section{REFERENCES}

ABEBE, B., ACOCELLA, V., KORME, T. \& AYALEW, D. (2007) Quaternary faulting and volcanism in the Main Ethiopian Rift. Journal of African Earth Sciences, 48, 115-124.

ALLEN, P.A. \& ALLEN J.R. (2013) Basin Analysis. Principles and Application to Petroleum Play Assessment. Wiley-Blackell, Chichester, 1019 p.

ACOCELLA, V. (2007) Understanding caldera structure and development: An overview of analogue models compared to natural calderas. Earth-Science Reviews, 85, 125-160.

ACOCELLA, V. (2014) Structural control on magmatism along divergent and convergent plate boundaries: Overview, model, problems. Earth-Science Reviews, 136, 226-288.

ACOCELLA, V., KORME, T., SALVINI, F. \& FUNICIELLO, R. (2002) Elliptic calderas in the Ethiopian Rift:control of pre-existing structures. Journal of Volcanology and Geothermal Research, 119, 189-203.

AGUIRRE-DíAZ, G.J., LABARTHE-HERNÁNDEZ, G., TRISTÁN-GONZÁLEZ, M., NIETO-OBREGÓN, J. \& GUTIÉRREZ-PALOMARES, I. (2008) The ignimbrite flare-up and graben caldera of the Sierra Madre Occidental, Mexico. In: Caldera Volcanism: analysis, modeling and response (Ed. by J. Gottsmann \& J. Martí), pp. 143-174. Elsevier, Amsterdam.

AGUIRRE-DÍAZ, G.J. \& LABARTHE, G. (2003) Fissure ignimbrites: Fissure-source origin for voluminous ignimbrites of the Sierra Madre Occidental and its relationship with Basin and Range faulting. Geology, 31, 773-776.

ALLAN, A.S.R., WILSON, C.J.N., MILLET, M.-A. \& WYSOCZANSKI, R.J. (2012) The invisible hand: Tectonic triggering and modulation of a rhyolitic supereruption. Geology, 40, 563-566.

BACKERT, N., FORD, M. \& MALARTRE, F. (2010) Architecture and sedimentology of the Kerinitis Gilbert-type fan delta, Corinth Rift, Greece. Sedimentology, 57, 543-586.

BAHK, J.J. \& CHOUGH, S.K. (1996) An interplay of syn- and inter-eruption depositional processes: the lower part of the Jangki Group (Miocene), SE Korea. Sedimentology 43, 421-438.

BAKER, B. H. (1986) Tectonics and volcanism of the southern Kenya Rift Valley and its influence on rift sedimentation. In: Sedimentation in the African Rifts (Ed. By L.E. Frostick, Renaut, R.W., Reid, I. \& Tiercelin, J.J.), Geological Society, Special Publication, 25, 4557.

BAKER, B. H. \& Mitchell, J.G. (1976) Volcanic stratigraphy and geochronology of the KedongOlorgesailie area and the evolution of the South Kenya rift valley. Journal of the Geological Society, London, 132, 467-484.

This article is protected by copyright. All rights reserved. 
BERNARD, B., VAN WYCK DE VRIES, B. \& LEYRIT, H. (2009) Distinguishing volcanic debris avalanche deposits from their reworked products: the Perrier sequence (French Massif Central). Bulletin of Volcanology, 71, 1041-1056.

BILMES, A., D'ELIA, L., FRANZESE, J.R., VEIGA, G.D. \& HERNÁNDEZ, M. (2013) Miocene block uplift and basin formation in the Patagonian foreland: The Gastre Basin, Argentina. Tectonophysics, 601, 98-111.

BLAIR, T.C. (2000) Sedimentology and progressive tectonic unconformities of the sheetflooddominated Hell's Gate alluvial fan, Death Valley, California. Sed. Geol., 132, 233-262.

BLAIR, T.C. \& MCPHERSON, J.G. (1994) Alluvial fans and their natural distinction from rivers based on morphology, hydraulic processes, sedimentary processes, and facies assemblages. J. Sediment. Res., 64, 450-489.

BLAIR, T.C. \& MCPHERSON J.G. (2008) Quaternary sedimentology of the Rose Creek fan delta, Walker Lake, Nevada, USA, and implications to fan-delta facies models. Sedimentology, 55, 579-615

BOSWORTH W., HUCHON, P. \& MCCLAY, K. (2005) The Red Sea and Gulf of Aden Basins. Journal of African Earth Sciences, 43, 334-378.

BRANTLEY, S.R. \& WAITT, R.B. (1988) Interrelations among pyroclastic surge, pyroclastic flow, and lahars in Smith Creek valley during first minutes of 18 May 1980 eruption of Mount St. Helens, USA. Bulletin of Volcanology, 50, 304-326.

BROWN, D.J. \& BELL, B.R. (2007) Debris flow deposits within the Palaeogene lava fields of NW Scotland: evidence for mass wasting of the volcanic landscape during emplacement of the Ardnamurchan Central Complex. Bulletin of Volcanology, 69, 847-868.

BUSBY, C.J. \& BASSETT, K.N. (2007) Volcanic facies architecture of an intra-arc strike-slip basin, Santa Rita Mountains, Southern Arizona. Bull Volcanol, 70, 85-103.

CABRERA, A.P \& CAFFE, P.J. (2009). The Cerro Morado Andesites: Volcanic history and eruptive styles of a mafic volcanic field from northern Puna, Argentina. Journal of South American Earth Sciences, 28, 113-131.

CAINENG, Z., GUANGYA, Z., RUKAI, Z., XUANJUN, Y. XIA, Z. LIANHUA, H. BAIHONG, W. \& XIAOZHI, W. (2013). Volcanic Reservoirs in Petroleum Exploration. Elsevier, Amsterdam.

CAS, R.A.F. \& WRIGHT, J.W. (1987) Volcanic successions: Modern and ancient. Chapman \& Hall, London.

CHAMBEFORT, I., LEWIS, B., WILSON, C.J.N., RAE, A.J., COUTTS, C., BIGNALL, G. \& IRELAND, T.R. (2014) Stratigraphy and structure of the Ngatamariki geothermal system from new zircon U$\mathrm{Pb}$ geochronology: Implications for Taupo Volcanic Zone evolution. Journal of Volcanology and Geothermal Research, 274, 51-70.

This article is protected by copyright. All rights reserved. 
CHERNET, T., HART, W.K., ARONSON, J.L. \& WALTER, R.C. (1998) New age constraints on the timing of volcanism and tectonism in the northern Main Ethiopian Rift-Southern Afar transition zone (Ethiopia). Journal of Volcanology and Geothermal Research, 80, 267-280.

CHOROWICZ, J. (2005) The East African rift system. Journal of African Earth Sciences, 43, 379-410.

CLAVERO, J.E., SPARKS, R.S.J., HUPPERT, H.E. \& DADE, W.B. (2002) Geological constraints on the emplacement mechanism of the Parinacota debris avalanche, northern Chile. Bulletin of Volcanology, 64, 40-54.

COLE, R.B. \& RIDGWAY, K.D. (1993) The influence of volcanism on fluvial depositional systems in a Cenozoic strike-slip basin, Denali fault system, Yukon Territory, Canada. J. Sediment. Res., 63, 152-166.

COLE, J.W., SPINKS, K.D., DEERING, C.D., NAIRN, I.A., \& LEONARD, G.S. (2010) Volcanic and structural evolution of the Okataina Volcanic Centre; dominantly silicic volcanism associated with the Taupo Rift, New Zealand. Journal of Volcanology and Geothermal Research, 190, 123-135.

COSTA, F. (2008) Residence Times of Silicic Magmas Associated with Calderas. In: Caldera Volcanism: analysis, modeling and response (Ed. by J. Gottsmann \& J. Martí), Amsterdam, Elsevier, 1-55.

COUSSOT, P. \& MEUNIER, M. (1996) Recognition, classification and mechanical description of debris flows. Earth-Science Reviews, 40, 209-227.

CRISTALLINI, E.O., BOTTESI, G., GAVARRINO, A., RODRIGUEZ, L., TOMEZZOLI, R.N. \& COMERON, R. (2006) Synrift geometry of the Neuquén Basin in the northeastern Neuquén Province, Argentina. In: Evolution of the Andean margin: a tectonic and magmatic view from the Andes

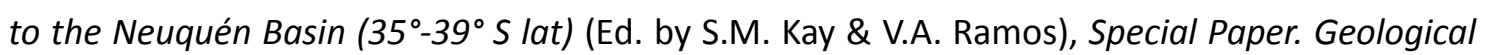
Society of America, 407, 147-161.

DAMBORENEA, S.E. \& MANCEÑIDO, M.O. (1993) Piedra Pintada. In: Léxico Estratigráfico de la Argentina, Volumen IX, Jurásico: 313 (Ed. by A.C. Riccardi \& S.E. Damborenea), Asociación Geológica Argentina, Serie "B" (Didáctica y Complementaria), 21, 313-316.

DAVIDSON, J. \& DE SILVA, S. (2000) Composite volcanoes. In: Encyclopedia of Volcanoes (Ed. by H. Sigurdsson, B. Houghton, S.R. McNutt, H. Rymer \& J. Stix), pp. 663-682. Academic Press, San Diego.

D’ELIA, L. (2010) Caracterización estratigráfica y estructural de la evolución temprana (sin-rift y postrift inicial) del margen sur de la Cuenca Neuquina entre Sañicó (Neuquén) y el río Limay (Río Negro) Universidad Nacional de La Plata (PhD Thesis), Argentina (255 pp.). ISBN: 978-950-340769-1. http://hdl.handle.net/10915/5320.

D'ELIA, L., BILMES, A., FRANZESE, J.R., VEIGA G.D., HERNÁNDEZ, M. \& MURAVCHIK, M. (2015) Early evolution of the southern margin of the Neuquén Basin, Argentina: tectono-stratigraphic

This article is protected by copyright. All rights reserved. 
implications and relevance in deep-hydrocarbon systems of the basin. Journal of South American Earth Sciences, 64, 42-57.

D’ELIA, L. \& MARTÍ, J. (2013) Caldera events in a rift depocentre: an example from the Jurassic Neuquén basin. Journal of the Geological Society, London, 170, 571-584.

D'ELIA, L., MURAVCHIK, M., FRANZESE, J.R. \& BILMES, A. (2012a) Syn-rift volcanism of the Neuquén Basin, Argentina: relationships with the Late Triassic-Early Jurassic evolution of the Andean margin. Andean Geology, 39, 106-132.

D'ELIA, L., MURAVCHIK, M., FRANZESE, J.R. \& LÓPEZ, L. (2012b) Tectonostratigraphic analysis of the Late Triassic-Early Jurassic syn-rift sequence of the Neuquén Basin in the Sañicó depocentre, Neuquén Province, Argentina. Andean Geology, 39, 133-157.

DOWNS, D.T., ROWLAND, J.V., WILSON, C.J.N., ROSENBERG, M.D., LEONARD, G.S. \& CALVERT, A.T. (2015) Evolution of the intra-arc Taupo-Reporoa Basin within the Taupo Volcanic Zone of New Zealand. Geosphere, 10, 185-206, doi:10.1130/GES00965.1.

DUPRAZ, C., VISSCHER, P.T., BAUMGARTNER, L.K. \& REID, R.P. (2004) Microbe-mineral interactions: early carbonate precipitation in a hypersaline lake (Eleuthera Island, Bahamas). Sedimentology, 51, 745-765.

EBINGER, C.J., DEINO, A.L., DRAKE, R.E. \& TESHA, A.L. (1989) Chronology of volcanism and rift basin propagation: Rungwe volcanic Province, East Africa. Journal of Geophysical Research, 94, 15785-15803.

EBINGER, C.J. \& CASEY, M. (2001) Continental break-up in magmatic provinces: An Ethiopian example, Geology, 29, 527-530.

EBINGER, C. \& SCHOLZ, C.A. (2012) Continental rift basins: an East African perspective. In: Tectonics of Sedimentary Basins: Recent Advances (Ed. by C. Busby \& A. Azor), 185-208. WileyBlackwell.

FENG, Z. (2008) Volcanic rocks as prolific gas reservoir: a case study from the Qingshen gas field in the Songliao Basin, NE China. Mar. Petrol. Geol., 25, 416-432.

FERGUSON, D.J., BARNIE, T.D. PYLE, D.M. OPPENHEIMER, C., YIRGU, G., LEWI, E., KIDANE, T., CARN, S. \& HAMLING, I. (2010.) Recent rift-related volcanism in Afar, Ethiopia. Earth and Planetary Science Letters, 292, 409-418.

FISHER, R. V. (1961) Proposed classification of volcaniclastic sediments and rocks. Geological Society of America Bulletin, 72, 1395-1408.

FISHER, R. V. \& SCHMINCKE, H.-U. (1984) Pyroclastic Rocks. Heidelberg, Springer, 474 p.

FISHER, R.V. \& SMITH, G.A. (1991) Sedimentation in volcanic settings, Special Publication. Society of Economic Paleontologists and Mineralogists, 45.

This article is protected by copyright. All rights reserved. 
FRANZESE, J.R. \& SPALLETTI, L.A. (2001) Late Triassic-early Jurassic continental extension in southwestern Gondwana: tectonic segmentation and pre-break-up rifting. Journal of South American Earth Sciences, 14, 257-270.

FRANZESE, J.R., VEIGA, G.D., SCHWARZ, E. \& GÓMEZ-PÉREZ, I. (2006) Tectonostratigraphic evolution of a Mesozoic graben border system: the Chachil depocentre, southern Neuquén Basin, Argentina. Journal of the Geological Society, 163, 707-721.

FRANZESE, J.R., VEIGA, G.D., MURAVCHIK, M., ANCHETA, D. \& D'ELIA, L. (2007) Estratigrafía de 'sinrift' (Triásico Superior-Jurásico Inferior) de la Cuenca Neuquina en la sierra de Chacaico, Neuquén, Argentina. Revista Geológica de Chile, 34, 49-62.

GAWTHORPE, R.L. \& LEEDER, M.R. (2000) Tectono-sedimentary evolution of active extensional basins. Basin Research, 12, 195-218.

GLICKEN, H.X. (1991) Sedimentary architecture of large volcanic- debris avalanches. In: Sedimentation in Volcanic Settings (Ed. by R.V. Fisher \& G.A Smith). Special Publication. SEPM, 45, 99-1.

GOODBRED, S.L.J. \& KUEHL, S.A. (2000) Enormous Ganges-Brahmaputra sediment discharge during strengthened early Holocene monsoon. Geology, 28, 1083-1086.

GRAVLEY, D.M., WILSON, C.J.N., LEONARD, G.S. \& COLE, J.W. (2007) Double trouble: Paired ignimbrite eruptions and collateral subsidence in the Taupo Volcanic Zone, New Zealand. Geological Society of America Bulletin, 119, 18-30.

GROEBER, P. (1946) Observaciones geológicas a lo largo del meridiano 70, Hoja Chos Malal. Revista de la Asociación Geológica Argentina, 1, 177-208.

GUDMUNDSSON, A. (2000) Dynamics of volcanic systems in Iceland: Example of Tectonism and Volcanism at Juxtaposed Hot Spot and Mid-Ocean Ridge Systems. Earth Planet. Sci., 28, 10740.

GULISANO, C.A., GUTIÉRREZ PLEIMLING, A.R. \& DIGREGORIO, R.E. (1984) Esquema estratigráfico de la secuencia jurásica del oeste de la provincia del Neuquén. In: IX Congreso Geológico Argentino, Actas I, 236-259.

HACKETT, W.R. \& HOUGHTON, B.F. (1989) A facies model for a Quaternary andesitic composite volcano: Ruapehu, New Zealand. Bull Volcanol, 51, 51-68.

HAYES, S.K., MONTGOMERY, D.R. \& NEWHALL, C.G. (2002) Fluvial sediment transport and deposition following the 1991 eruption of Mount Pinatubo. Geomorphology, 45, 211- 224.

HAUGHTON, P.D.W. (1993) Simultaneous dispersal of volcaniclastic and non-volcanic sediments in fluvial basins: examples from the Lower Old Red Sandstone, eastcentral Scotland. In: Alluvial

This article is protected by copyright. All rights reserved. 
Sedimentation (Ed. by M. Marzo \& C. Puigdefabregas), Spec. Pub. International Association of Sedimentologists, 17, 451-471.

HINTERWIMMER, G. (2002) Los reservorios de la Serie Tobífera. In: Rocas reservorio de las cuencas productivas de la Argentina (Ed. by M. Schiuma, G. Hinterwimmer \& G. Vergani), pp. 27-47. Instituto Argentino de Petróleo y Gas, Buenos Aires.

HOWELL, J.A., SCHWARZ, E., SPALLETTI, L.A. \& VEIGA, G.D. (2005) The Neuquén Basin: an overview. In: The Neuquén Basin, Argentina: A Case Study in Sequence Stratigraphy and Basin Dynamics (Ed. by G.D. Veiga, L.A. Spalletti, J.A. Howell \& E. Schwarz), Special Publications. Geological Society, London, 252, 1-14.

KARÁTSON, D. \& NÉMETH, K. (2001) Lithofacies associations of an emerging volcaniclastic apron in a Miocene volcanic complex: an example from the Börzsöny Mountains, Hungary. Int J Earth Sciences, 90, 776-794.

LARA, L.E. (2009) The 2008 eruption of the Chaitén Volcano, Chile: a preliminary report. Andean Geology, 36, 125-129.

LEANZA, H.A., MAZZINI, A., CORFU, F., LLAMBíAS, E.J., SVENSEN, H., PLANKE, S. \& GALLAND, O. (2013) The Chachil Limestone (Pliensbachian earliest Toarcian) Neuquén Basin, Argentina: U$\mathrm{Pb}$ age calibration and its significance on the Early Jurassic evolution of southwestern Gondwana. J. S. Am. Earth Sci., 42, 171-185.

LEEDER, M.R. \& GAWTHORPE, R.L. (1987) Sedimentary models for extensional tilt-block/half-graben basins (Ed. by M.P. Coward, J.F. Dewey \& P.L. Hancock), Special Publications. Geological Society, London, 28, 139-152.

LEEDER, M.R., MACK, G.H. \& SALYARDS, S.L. (1996) Axial-transverse fluvial interactions in half-graben: Plio-Pleistocene Palomas Basin, southern Río Grande Rift, New Mexico, USA. Basin Research, $12,225-241$.

LE CORVEC, N. \& WALTER, T.R. (2009) Volcano spreading and fault interaction influenced by rift zone intrusions: Insights from analogue experiments analyzed with digital image correlation technique. Journal of Volcanology and Geothermal Research, 183,170-182.

LEGARRETA, L. \& ULIANA, M.A. (1996) The Jurassic succession in west-central Argentina: stratal pattern, sequences and paleogeographic evolution. Palaeogeography, Palaeoclimatology, Palaeoecology, 120, 303-330.

LEGARRETA, L., VILLAR. H.J., CRUZ, C.E., LAFFITTE G.A. \& VARADÉ, R. (2008) Revisión integrada de los sistemas generadores, estilos de migración-entrampamiento y volumetría de hidrocarburos en los distritos productivos de la Cuenca Neuquina. In: Sistemas Petroleros de las Cuencas

This article is protected by copyright. All rights reserved. 
Andinas (Ed. by C.E. Cruz, J.F. Rodríguez, J.J. Hechem \& J.H. Villar), pp. 79-108. Instituto Argentino del Petróleo y del Gas, Buenos Aires.

LENHARDT, N. \& GÖTZ, A. (2011) Volcanic settings and their reservoir potential: An outcrop analog study on the Miocene Tepoztlán Formation, Central Mexico. Journal of Volcanology and Geothermal Research, 204, 66-75.

LIPMAN, P.W. (1976) Caldera-collapse breccias in the western San Juan Mountains, Colorado. Geol. Soc. Am. Bull., 87, 1397-1410.

LIPMAN, P.W. (2000) Calderas. In: Encyclopedia of Volcanoes (Ed. by H. Sigurdsson, B. Houghton, S.R. Mcnutt, H. Rymer \& J. Stix), pp. 643-662. Academic Press, San Diego.

MANVILLE A, V., NÉMETH, K. \& KANO, C. (2009) Source to sink: A review of three decades of progress in the understanding of volcaniclastic processes, deposits, and hazards. Sedimentary Geology, 220,136-161.

MARTí, J. (1991) Caldera-like structures related to Permo-Carboniferous volcanism of the Catalan Pyrenees (NE Spain). Journal of Volcanology and Geothermal Research, 45, 173-186.

MARTINA, F.,DÁVILA, F.M. \& ASTINI, R.A. (2006) Mio-Pliocene volcaniclastic deposits in the Famatina Ranges, southern Central Andes: A case of volcanic controls on sedimentation in broken foreland basins. Sedimentary Geology, 186, 51-65.

MATHISEN, M.E. \& MCPHERSON, J.G. (1991) Volcaniclastic deposits: implications for hydrocarbon exploration. In: Sedimentation in Volcanic Settings (Ed. by R.V. Fisher \& G.A. Smith), Special Publication. Society of Economic Paleontologists and Mineralogists, 45, 27-36.

MCPHIE, J., DOYLE, M. \& ALLEN, R. (1993) Volcanic Textures: A Guide to the Interpretation of Textures in Volcanic Rocks. CODES - University of Tasmania.

MCPHERSON, J.G., SHANMUGAM, G. \& MOIOLA, R.J. (1987) Fan-deltas and braid deltas: varieties of coarse-grained deltas. Bull. Geol. Soc. Am., 99, 331-340.

MOORE, I. \& KOKELAAR, P. (1997) Tectonic influences in piecemeal caldera collapse at Glencoe Volcano, Scotland. Journal of the Geological Society, London, 154, 765-768.

MOORE, I. \& KOKELAAR, P. (1998) Tectonically controlled piecemeal caldera collapse: A case study of Glencoe volcano, Scotland. Geological Society of America Bulletin, 110, 1448-1466.

MOREL, E.M. \& GANUZA, D.G. (2002) Paso Flores. In: Léxico Estratigráfico de la Argentina, Volumen VIII, Triásico: 208 (Ed. by P.N. Stipanicic \& C.A. Marsiscano), Asociación Geológica Argentina, Serie B (Didáctica y Complementaria), 26, 208-209.

MORLEY, C.K. (1999). Geosciences of Rift Systems-Evolution of east Africa. The American Association of Petroleum Geologists Studies in Geology, 44.

This article is protected by copyright. All rights reserved. 
MURAVCHIK, M. (2009) Controles estructurales y volcánicos sobre las secuencias de sin-rift (Precuyano) de la Cuenca Neuquina. (PhD Thesis) Universidad Nacional de La Plata, Argentina (291 pp.).

MURAVCHIK, M., BILMES, A., D'ELIA, L. \& FRANZESE, J.R. (2014) Alluvial fan deposition along a rift depocentre border from the Neuquén Basin, Argentina. Sedimentary Geology, 301, 70-89

MURAVCHIK, M., D'ELIA, L., BILMES, A. \& FRANZESE, J.R. (2011) Syn-eruptive/inter-eruptive relations in the syn-rift deposits of the Precuyano Cycle, Sierra de Chacaico, Neuquén Basin, Argentina. Sedimentary Geology, 238, 132-144.

NEMEC, W. (1990) Aspects of sediment movement on steep delta slopes. In: Coarse-Grained Deltas (Ed. by A. Colella \& D.B. Prior), Special Publication. International Association of Sedimentologists, 10, 29-73.

NÉMETH, K. (2010) Monogenetic volcanic fi elds: Origin, sedimentary record, and relationship with polygenetic volcanism. Geological Society of America, Special Paper, 470, 43-66.

NÉMETH, K., \& KERESZTURI, G. (2015) Monogenetic volcanism: personal views and discussion. Int J Earth Sci, 104, 2131-2146.

NÉMETH, K. \& MARTIN, M. (2007) Practical Volcanology. Lecture notes for understanding volcanic rocks from field-based studies. Geological Institute of Hungary, Occasional Papers, 27, Budapest.

NISHIKIA, K., TAKAHASHIB, K., MATSUMOTOA, A. \& MIYAKE, Y. (2011) Quaternary volcanism and tectonic history of the Suwa-Yatsugatake Volcanic Province, Central Japan. Journal of Volcanology and Geothermal Research, 203,158-167.

ORTON, G.J. (2002) Volcanic environments. In: Sedimentary Environments: Processes, Facies and Stratigraphy (Ed.by R.G. Reading), pp. 485-567. Blackwell Science, Oxford.

PALMER, B.A. \& NEALL, V.E. (1991) Contrasting lithofacies architecture in ring-plain deposits related to edifice construction and destruction, the Quaternary Stratford and Opunake Formations, Egmont Volcano, New Zealand. Sedimentary Geology, 74, 71-88.

PALMER, B.A., ALLOWAY, B.V. \& NEALL, V.E. (1991) Volcanic-debris-avalanche deposits in New Zealand-lithofacies organization in unconfined,wet-avalanche flows. In: Sedimentation in Volcanic Settings (Ed. by R.V. Fisher \& G.A. Smith), Special Publication. Society of Economic Paleontologists and Mineralogists, 45, 89-98.

PALMER, B.A., PURVES, A.M. \& DONOGHUE, S.L. (1993) Controls on accumulation of a volcaniclastic fan, Ruapehu composite volcano, New Zealand. Bulletin of Volcanology, 55, 176-189.

PÁNGARO, F., CORBERA, R., CARBONE, O. \& HINTERWIMMER, G. (2002) Los reservorios del Precuyano. In: Rocas Reservorio de las Cuencas Productivas Argentinas (Ed. by M. Schiuma, G.

This article is protected by copyright. All rights reserved. 
Hinterwimmer \& G.D. Vergani), pp. 229-254. Instituto Argentino del Petróleo y del Gas, Buenos Aires.

PÁNGARO, F., PEREIRA, D.M. \& MICUCCI, E. (2009) El sinrift de la dorsal de Huincul, Cuenca Neuquina: evolución y control sobre la estratigrafía y estructura del área. Revista de la Asociación Geológica Argentina, 65, 265-277.

PAREDES, J.M., FOIX, N., COLOMBO, F.N., NILLNI, A., ALLARD, J.O. \& R.A. Marquillas (2007) Volcanic and climatic controls on fluvial style in a high-energy system: the Lower Cretaceous Matasiete Formation, Golfo San Jorge basin, Argentina. Sedimentary Geology, 202, 96-123.

PARFITT, L. \& WILSON, L. (2008). Fundamentals of Physical Volcanology. Blackwell Scientific Publications, Oxford

PETTERSON, M. G., BedDOE-STEPHENS, B., MILlWARD, D. \& JOHNSON, E. W. (1992) A pre-caldera plateau-andesite field in the Borrowdale Volcanic Group of the English Lake District. Journal of the Geological Society, London, 149, 889-906.

PIERSON, T.C., JANDA, R.J., THOURET, J.C. \& BORRERO, C.A. (1990) Perturbation and melting of snow ice by the 13 November eruption of the Nevado Del Ruiz, Colombia, and consequent mobilization, flow and deposition of lahars. Journal of Volcanology and Geothermal Research, 41, 17-66.

POSTMA, G. (1983) Water escape structures in the context of a depositional model of a mass flow dominated conglomeratic fan-delta (Abrioja Formation, Pliocene, Almeria Basin, SE Spain). Sedimentology, 30, 91-103.

POSTMA, G. (1990) Depositional architecture and facies of river and fan deltas: a synthesis. In: Coarse-Grained Deltas (Ed. by A. Colella \& D.B. Prior), IAS Special Publication, 10, 13-27.

RAMOS, M.E., FOLGUERA, A., FENNELL, L., GIMÉNEZ, M. LITVAK, V.D, DZIERMA, Y. \& RAMOS, V.A. (2014) Tectonic evolution of the North Patagonian Andes from field and gravity data (39-40 $\mathrm{S}$ ). Journal of South American Earth Sciences, 51, 59-75.

RAMOS, V.A. (2009) Anatomy and global context of the Andes: main geologic features and the Andean orogenic cycle. In: Backbone of the Americas: Shallow Subduction, Plateau Uplift, and Ridge and Terrane Collision (Ed. by S.M. Kay, V.A. Ramos \& W.R. Dickinson). Geological Society of America Memoir, 204, 31-65.

RAVNÅS, R., \& STEEL, R. J. (1998) Architecture of Marine Rift-Basin Successions. AAPG Bulletin, 82, 110-146.

READING, H.G. \& COLLINSON, J.D. (2002) Clastic coasts. In: Sedimentary Environments: Processes, Facies and Stratigraphy (Ed. by H.H. Reading), pp. 154-231. Blackwell Science, Oxford.

This article is protected by copyright. All rights reserved. 
RIDING, R. (2000) Microbial carbonates: the geological record of calcified bacterial-algal mats and biofilms. Sedimentology, 47, 179-214.

RIGGS, N.R., HURLBERT, J.C., SCHROEDER, T.J., WARD, S.A. (1997) The interaction of volcanism and sedimentation in the proximal areas of a Mid-Tertiary volcanic dome field, Central Arizona, USA. J. Sedimentary Research, 67, 142-153.

ROWLAND, J.V. \& SIBSON, R.H. (2001) Extensional fault kinematics within the Taupo Volcanic Zone, New Zealand: Soft-linked segmentation of a continental rift system. New Zealand Journal of Geology and Geophysics, 44, 271-283..

ROWLAND, J.V., WILSON, C.J.N. \& GRAVLEY, D.M. (2010) Spatial and temporal variations in magmaassisted rifting, Taupo Volcanic Zone, New Zealand. Journal of Volcanology and Geothermal Research, 190, 89-108.

SCHIUMA, M. \& LLAMBÍAS, E.J. (2008) New ages and chemical analysis on Lower Jurassic volcanism close to the Huincul High, Neuquén. Revista de la Asociación Geológica Argentina, 63, 644652.

SCHLISCHE, R.W. (1991) Half-graben basin filling models: new constraints on continental extensional basin development. Basin Research, 3, 123-141.

SCHLISCHE, R.W. (1992) Structural and stratigraphic development of the Newark extensional basin, eastern North America: evidence for the growth of the basin and its bounding structures. Geological Society of America Bulletin, 104, 1246-1263.

SCHLISCHE, R.W. \& ANDERS, M.H. (1996) Stratigraphic effects and tectonic implications of the growth of normal faults and extensional basins. Geological Society of America, Special paper, 303, 183-203.

SCHNEIDER, J. \& FISHER, R.V. (1998) Transport and emplacement mechanisms of large volcanic debris avalanches: evidence from the northwest sector of Cantal Volcano (France). Journal of Volcanology and Geothermal Research, 83, 141-165.

SCOTT, K.M., JANDA, R.J., DE LA CRUZ, E.G., GABINETE, E., ETO, I., ISADA, M., SEXTON, M. \& HADLEY, K.C. (1996a) Channel and sedimentation responses to large volumes of 1991 volcanic deposits on the east flank of Mount Pinatubo. In: Fire and Mud, Eruptions and Lahars of Mount Pinatubo, Philippines (Ed. by C.G. Newhall \& R.S. Punongbayan), pp. 971-988. PHIVOLCS Press, Quezon City, and University of Washington Press, Seattle.

SCOTT, W.E., HOBLITT, R.P., TORRES, R.C., SELF, S., MARTINEZ, M.M.L. \& NILLOS, T. (1996b) Pyroclastic flows of the June 15, 1991, climactic eruption of Mount Pinatubo. In: Fire and Mud, Eruptions and Lahars of Mount Pinatubo, Philippines (Ed. by C.G. Newhall \& R.S. Punongbayan), pp. 545570. PHIVOLCS Press, Quezon City, and University of Washington Press, Seattle.

This article is protected by copyright. All rights reserved. 
SHULTZ, A.W. (1984) Subaerial debris-flow deposition in the upper Paleozoic Cutler Formation, Western Colorado. Journal of Sedimentary Petrology, 54, 759-772.

SIEBERT, L. (1984) Large volcanic debris avalanches: characteristics of source areas, deposits, and associated eruptions. Journal of Volcanology and Geothermal Research, 22, 163-197.

SKILLING, I.P. (1993) Incremental caldera collapse of Suswa volcano, Gregory Rift Valley, Kenya. Journal of the Geological Society, London, 150, 885-896.

SMITH, G. A. (1986) Coarse-Grained Nonmarine Volcaniclastic Sediment - Terminology and Depositional Process. Geological Society of America Bulletin, 97, 1-10.

SMITH, G.A. (1987) The influence of explosive volcanism on fluvial sedimentation: the Deschutes Formation (Neogene) in Central Oregon. Journal of Sedimentary Petrology, 57, 613-629.

SMITH, G.A. \& LOWE, D.R. (1991) Lahars: Volcano-hydrologic events and deposition in the debris flow-hyperconcentrated flow continuum. In: Sedimentation in Volcanic Settings (Ed. by R.V. Fisher \& G.A. Smith). Special Publication, Society of Economic Paleontologists and Mineralogists, 45, 59-70.

SMITH, G.A. (1988) Neogene synvolcanic and syntectonic sedimentation in central Washington. Geol. Soc. Am. Bull. 100, 1479-1492.

SPALlETTI, L.A., FRANZESE, J.R., MOREL, E., D’ELIA, L., ZÚÑIGA, A. \& FANNING, C.M. (2010) Consideraciones acerca de la sedimentología, paleobotánica y geocronología de la Formación Piedra del Águila (Jurásico Inferior, Neuquén, República Argentina). Revista de la Asociación Geológica Argentina, 66, 305-313.

SPINKS, K.D., ACOCELLA, V., COLE, J.W. \& BASSETT, K.N. (2005) Structural control of volcanism and caldera development in the transtensional Taupo Volcanic Zone, New Zealand. Journal of Volcanology and Geothermal Research, 144, 7-22.

SRUOGA, P. \& RUBINSTEIN, N. (2007) Processes controlling porosity and permeability in volcanic reservoirs from the Austral and Neuquén basins. Argentina. AAPG Bull. 91, 115-129.

STIPANICIC, P.N. (1969) El avance de los conocimientos del Jurásico argentino a partir del esquema de Groeber. Revista de la Asociación Geológica Argentina, 24, 367-388.

STIPANICIC, P.N., RODRIGO, F., BAULIES, O.L. \& MARTíNEZ, C.G. (1968) Las formaciones presenonianas en el denominado Macizo Nordpatagónico y regiones adyacentes. Revista de la Asociación Geológica Argentina, 23, 67-98.

TALBOT, M.R. \& ALLEN, P.A. (2002) Lakes. In: Sedimentary environments: Processes, Facies and Stratigraphy (Ed. by H.G. Reading), pp. 83-124. Blackwell Science, Oxford.

THOURET, J.-C. (1999). Volcanic geomorphology-an overview. Earth-Science Reviews, 47, 95-131.

This article is protected by copyright. All rights reserved. 
TUCKER, M. E. (2001) Sedimentary petrology, an introduction to the origin of sedimentary rocks. 3rd ed. Blackwell Scientific Publications, Oxford.

UI, T., TAKARADA, S. \& YOSHIMOTO, M. (2000) Debris avalanches. In: Encyclopedia of Volcanoes (Ed. by H. Sigurdsson, B. Houghton, S.R. McNutt, H. Rymer \& J. Stix), pp. 617-626. Academic Press, San Diego.

UMAZANO, A.M., MELCHOR R.N., BEDATOU, E., BELLOSI, E.S. \& KRAUSE, J.M. (2014) Fluvial response to sudden input of pyroclastic sediments during the 2008-2009 eruption of the Chaitén Volcano (Chile): the role of logjams. Journal of South American Earth Sciences, 54, 140-157.

VAN WYK DE VRIES, B. \& FRANCIS, P.W. (1997) Catastrophic collapse at stratovolcanoes induced by gradual volcanic spreading. Nature, 387, 387-390.

VARELA, R., DALLA SALDA, L., CINGOLANI, C. \& GÓMEZ, V. (1991) Estructura, petrología y geocronología del basamento de la región del Río Limay del Río Negro y Neuquén, Argentina. Revista Geológica de Chile, 18, 147-163.

VERGANI, G.D., TANKARD, A.J., BELOTTI, H.J. \& WEISINK, H.J. (1995) Tectonic evolution and paleogeography of the Neuquén basin, Argentina. In: Petroleum basins of South America (Ed. by A.J. Tankard, S.R. Suárez \& L.H. Welsink), Memoir, American Association of Petroleum Geologists, 62, 383-402.

VESSELL, R.D. \& DAVIES, D.K. (1981) Nonmarine sedimentation in an active fore arc basin. In: Nonmarine Depositional Environments: Models for Exploration (Ed. by F.G. Ethridge \& R.M. Flores), Special Publication. Society of Economic Paleontologists and Mineralogists, 31, 34-45.

WALKER, G.P.L. (2000) Basaltic volcanoes and volcanic systems. In: Encyclopedia of Volcanoes (Ed. by H. Sigurdsson, B. Houghton, S.R. McNutt, H. Rymer \& J. Stix), pp. 283-290. Academic Press, San Diego.

WILSON, C.J.N., GRAVLEY, D.M., LEONARD, G.S. \& ROWLAND, J.V. (2009) Volcanism in the central Taupo Volcanic Zone, New Zealand: Tempo, styles, and controls. In: Studies in volcanology: The legacy of George Walker (Ed. by T. Thordarson, S. Self, G. Larsen, S.K. Rowland \& Á. Höskuldsson), pp. 225-247. Geological Society of London, London.

WHITE, J. D. L. \& HOUGHTON, B. F. (2006) Primary volcaniclastic rocks. Geology, 34, 677-680.

WOLFENDEN, E., EBINGER, C., DEINO, A., \& AYALEW, D. (2005) Evolution of a volcanic rifted margin: Southern Red Sea, Ethiopia. GSA Bulletin, 117, 846-864.

WOLFENDEN, E., YIRGU, G., EBINGER, C., DEINO, A., \& AYALEW, D. (2004) Evolution of the northern Main Ethiopian Rift: Birth of a triple-junction. Earth and Planetary Science Letters, 24, 213228.

This article is protected by copyright. All rights reserved. 
WOOLLER, L., VAN WYCK DE VRIES, B., CECCHI, E. \& RYMER, H. (2009) Analogue models of the effect of long-term basament fault movement on volcanic edifices. Bulletin of Volcanology, 71, 11111131.

ZANCHETTA, G., SULPICIO, R. \& DI VITO, M.A. (2004) The role of volcanic activity and climate in alluvial fan growth at volcanic areas: an example from southern Campania (Italy). Sedimentary Geology, 168, 249-280.

ZIEGLER, P.A. \& CLOETINGH, S. (2004) Dynamic processes controlling evolution of rifted basins. EarthScience Reviews, 64, 1-50.

\section{FIGURE LEGENDS:}

Figure 1. Location map showing the distribution of the surface and subsurface rift depocentres in the Neuquén Basin, Argentina (modified from Franzese and Spalletti, 2001). Location of the study area is highlighted with a rectangle.

Figure 2. Schematic stratigraphic column of the Sañicó depocentre (Neuquén Basin) showing the different stratigraphic and tectono-stratigraphic units of the study area.

Figure 3. (A) Map of the major structures recognized at surface and subsurface of the southern part of the Neuquén rift basin. Location of the Sañicó depocentre is highlighted with a rectangle. Modified from Vergani et al. (1995, 2005), D’Elia \& Martí (2013) and D’Elia et al. (2015). (B) Geologic map and stratigraphy of the study area. (C) Cross-section of the Sañicó depocentre.

Figure 4. (A) Detailed geological map of the Sañicó depocentre and location of stratigraphic logs shown in Figure 4b (Modified from D'Elia \& Marti, 2013; D'Elia et al., 2015). (B) Stratigraphic logs of the syn-rift succession of the Sañicó depocentre. Mst, mudstones; Sst, sandstones; Congl, conglomerates; F, fine; $\mathrm{M}$, medium; C, coarse. (C) Percentage of lava, pyroclastic and sedimentary products measured for each member. (D) Correlation panels perpendicular (NW-SE-oriented) and parallel (NE-SW-oriented) to the trend of the Sañicó depocentre (see logs in Fig. 4a for location).

Figure 5. Conceptual model showing the syn-rift evolution of the Sañicó depocentre (modified from D’Elia \& Martí, 2013).

This article is protected by copyright. All rights reserved. 
Figure 6. Lower stage volcanic units. (A) Detailed correlation panel showing the relationships between sedimentary and volcanic units of the Lower Stage (see Fig. 4 for location). (B) Photograph of the coherent sheet andesitic lava flows located close to the master fault of the depocentre. (C) Andesitic block lava flow occurring towards the inner part of the depocentre. (D) Outcrop-scale photograph of the lapilli-tuff ignimbrite facies with horizontal stratification. (E) Plug intrusion recorded at the boundary fault system. (F) Detail of autobrecciated carapace of sheet lava flows.

Figure 7. Lower stage sedimentary units. (A) Sedimentary logs showing the lateral and vertical correlation of volcaniclastic breccia-conglomerate unit (to the top) and channelized volcaniclastic conglomerate-sandstone unit (to the bottom). (B) Detailed correlation panel showing the relationships between the sedimentary and volcanic units of the lower stage.

Figure 8. (A) Outcrop scale-photograph of massive matrix-supported to clast-supported breccias formed by volcanic debris avalanches. (B) Lobate body successions composed of massive matrixsupported conglomerates deposited by debris flows. (C) Photograph of channelized volcaniclastic conglomerates and sandstones $(\mathrm{SH}$, sandy hyperconcentrated flow deposits; $\mathrm{GH}$, gravelly hyperconcentrated flow deposits; SX, cross-stratification sandstone facies originated by waning phases of the flows). (D) Detail of the matrix of volcanic debris avalanche deposits. (E) Detail of debris flow deposits. (F) Gravelly hyperconcentrated flow deposits. (G) Sandy hyperconcentrated flow deposits.

Figure 9. Microphotographs showing the different provenances of the volcanic syn-rift succession. (A) and (B) Microphotographs of the matrix of an avalanche flow deposit at proximal (A) and distal positions (B). Note the fragmented feldspar crystal (FC) and the andesitic monomictic composition of the lithoclasts (AL). (C) Microphotograph of the matrix of a debris flow deposit. Note the predominance of andesitic lithoclasts with different alteration and texture features. (D) Microphotograph of monomictic tuffaceous sandstones (PF, pyroclastic fragment; FC, feldspar crystal). (E) Microphotograph of the matrix of conglomerates of the upper stage deposits. (F) Microphotograph of microbial lamination in stromatolitic lacustrine deposits.

Figure 10. Middle stage volcanic units. (A) Correlation panel showing the relationships between the sedimentary and volcanic units of the middle stage. (B) Thick intra (graben) caldera ignimbrite overlying the Lower Stage units through a sharp unconformity. (C) Detail of co-ignimbrite lithic breccias located close to volcano-tectonic faults that acted during graben caldera events. (D) Outcrop

This article is protected by copyright. All rights reserved. 
photography of the intracaldera lapilli-tuff ignimbrite facies. (E) Post-eruptive acid intrusive dome related to major volcano-tectonic faults located at the boundary position of the depocentre.

Figure 11. Middle stage sedimentary units. (A) Outcrop-scale photograph of the syn-eruptive ash/pumiceous-rich volcaniclastic sandstone and breccia deposits (I, intracaldera ignimbrite units; SED, syn-eruptive deposits). (B) Sedimentary logs showing the syn-eruptive ash/pumiceous-rich volcaniclastic sandstone and breccia deposits (see figures 4 and 10 for the location of the sedimentary sections and the detailed correlation panel showing the relationships of the upper stage units). (C) Photograph of massive pumiceous breccias interbedded with massive to horizontally stratified pebbly tuffaceous sandstone, formed by hyperconcentrated flows. (D) Detail of massive pumiceous breccias with transitional contacts and normal grading.

Figure 12. Upper stage volcanic units. (A) Detailed correlation panel showing the relationships of the upper stage units. (B) Outcrop-scale photograph of the lacustrine deposits interbedded with lava flow units. (C) Outcrop-scale photograph of the sheet lava flows base, showing veins and filled vesicles formed by interaction between lava flows and wet sediment. (D) Detail of veins and filled vesicles shown in (C).

Figure 13. Upper stage sedimentary units. Sedimentary logs showing the passage from conglomerates and sandstones of alluvial/delta facies to siltstones and stromatolitic lacustrine deposits (see figures 4 and 12 for the location of the sedimentary sections and the detailed correlation panel showing the relationships of the upper stage units).

Figure 14. (A) Outcrop-scale photograph of fan-delta deposits. (B) Tabular body with slightly erosive bases formed by large-scale cross-stratified clast-supported conglomerates deposited at a delta front. (C) and (D) Sandstone facies interbedded with conglomerate foreset facies. (E), (F) and (G) Laminated to massive sandstone facies at the bottomset of delta front. $(\mathrm{H})$ and $(\mathrm{I})$ Outcrop-scale photograph of silicified limestone and siltstone deposits originated in a shallow lacustrine environment. (J) Detail of the limestone and siltstone deposits.

Figure 15. Cause and effect model showing the volcanic variables that control the different parameters of the sedimentary environments defined for the three different volcanic scenarios recorded in the Sañicó depocentre (variability of the monogenetic-polygenetic volcanoes was 
modified from Németh \& Kereszturi, 2015). Schematic basin infill models for each case are illustrated at the bottom.
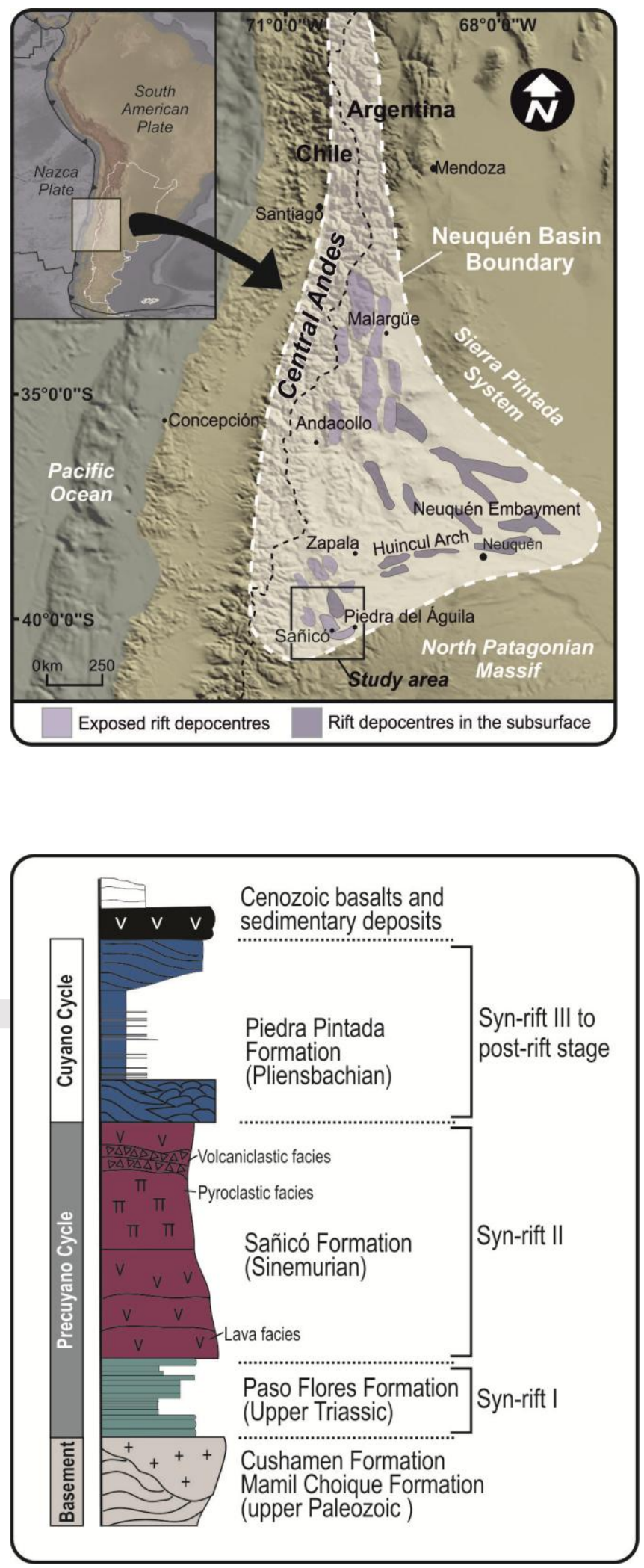

This article is protected by copyright. All rights reserved. 


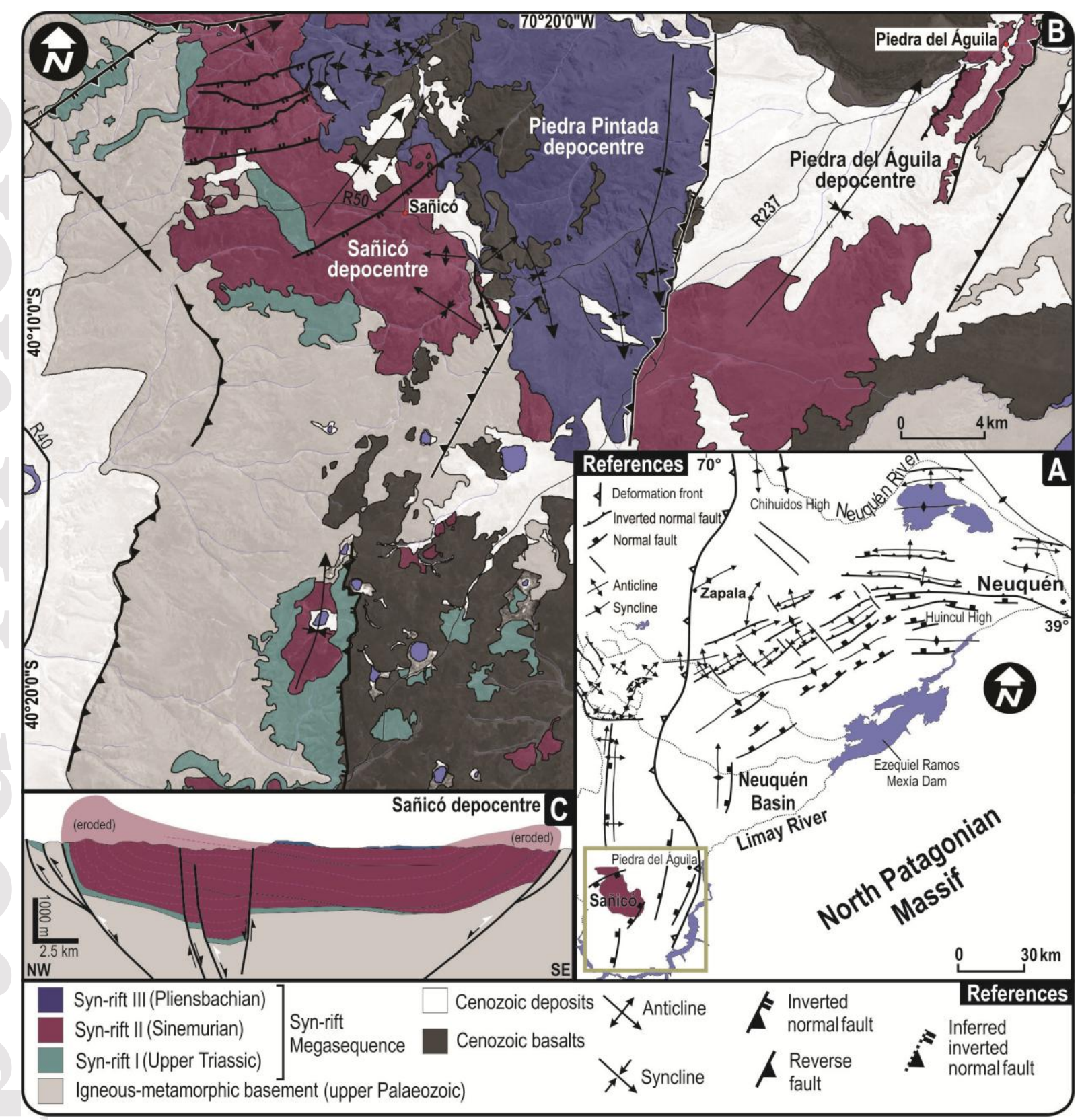

This article is protected by copyright. All rights reserved. 

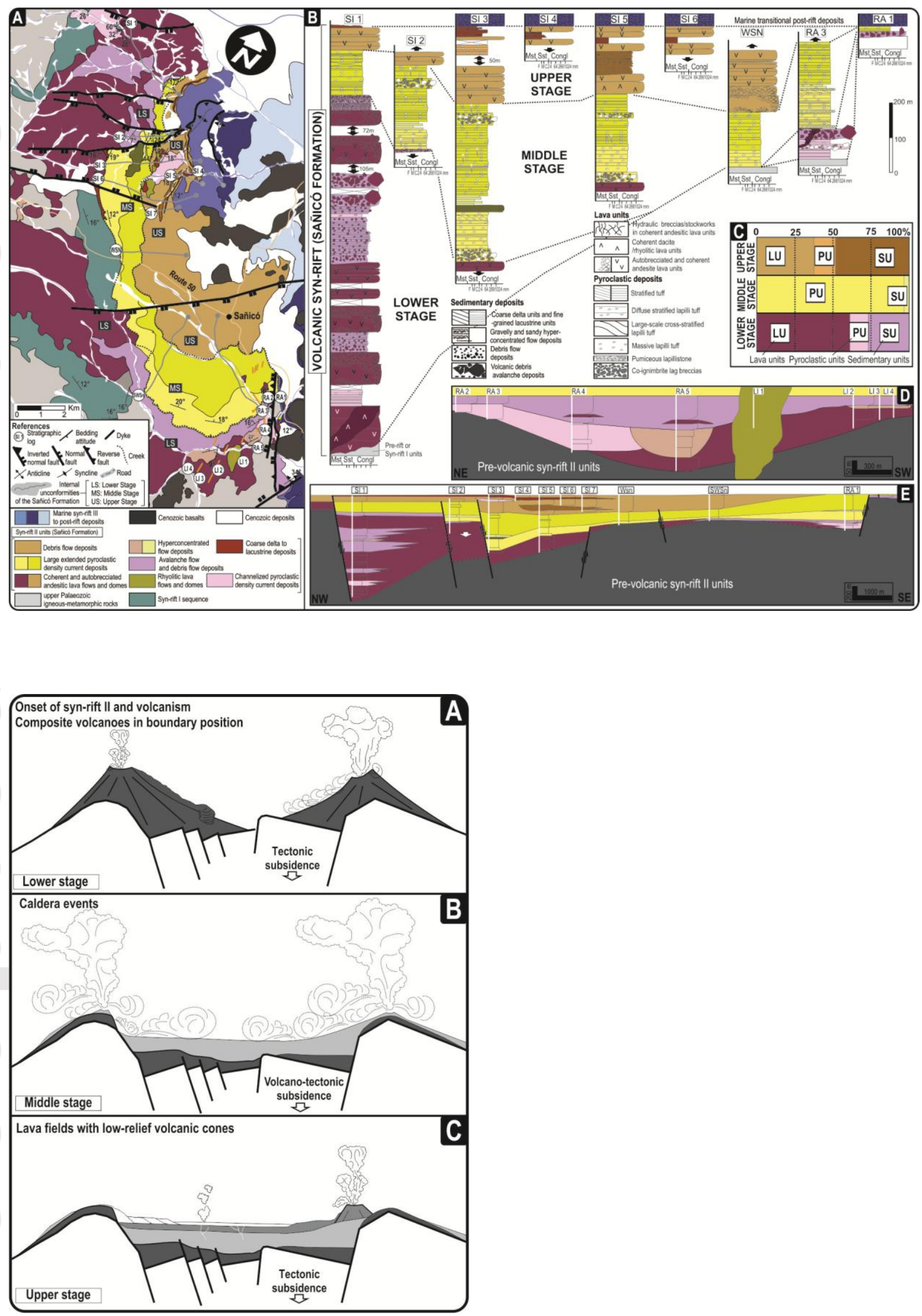

This article is protected by copyright. All rights reserved. 


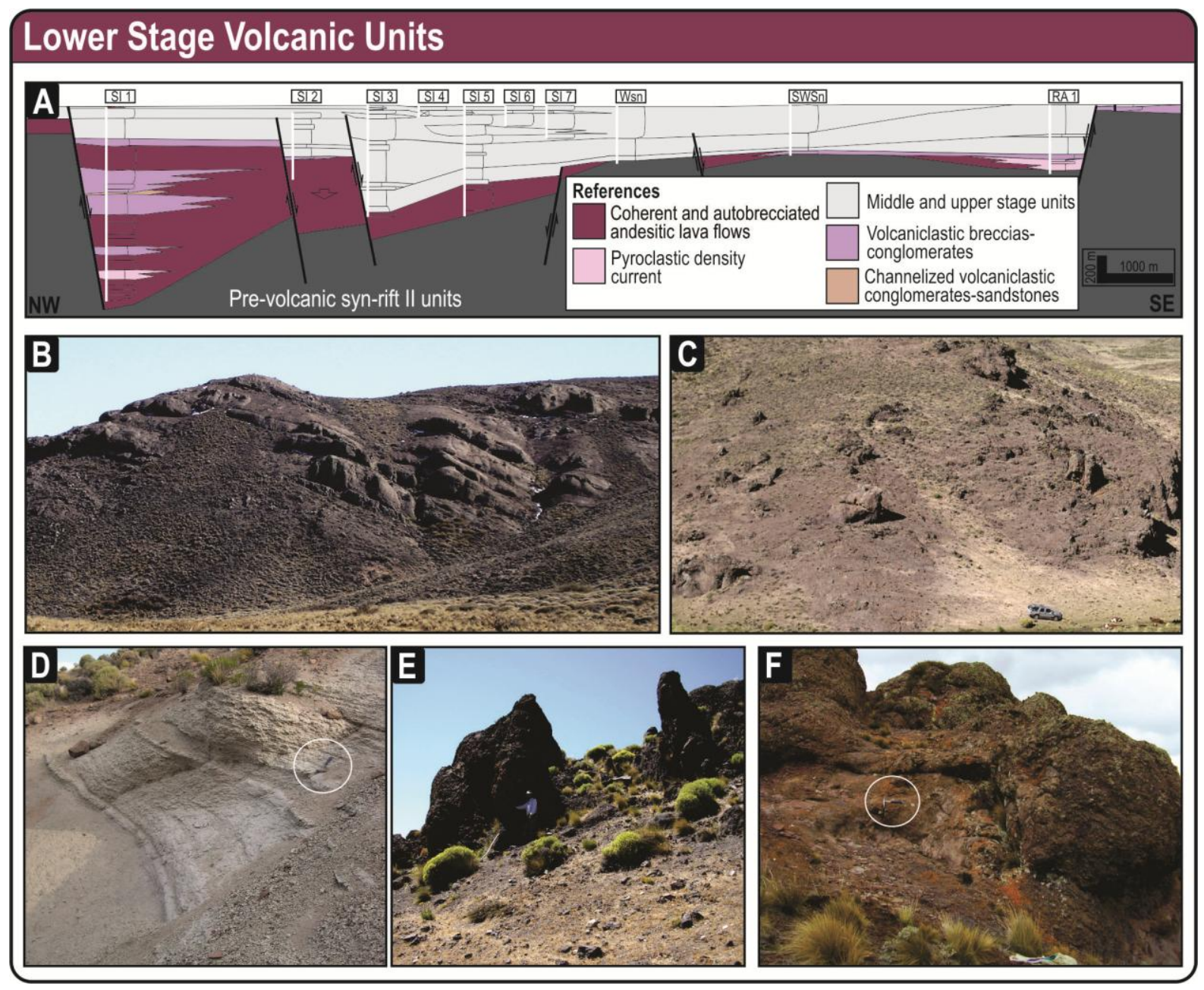

This article is protected by copyright. All rights reserved. 


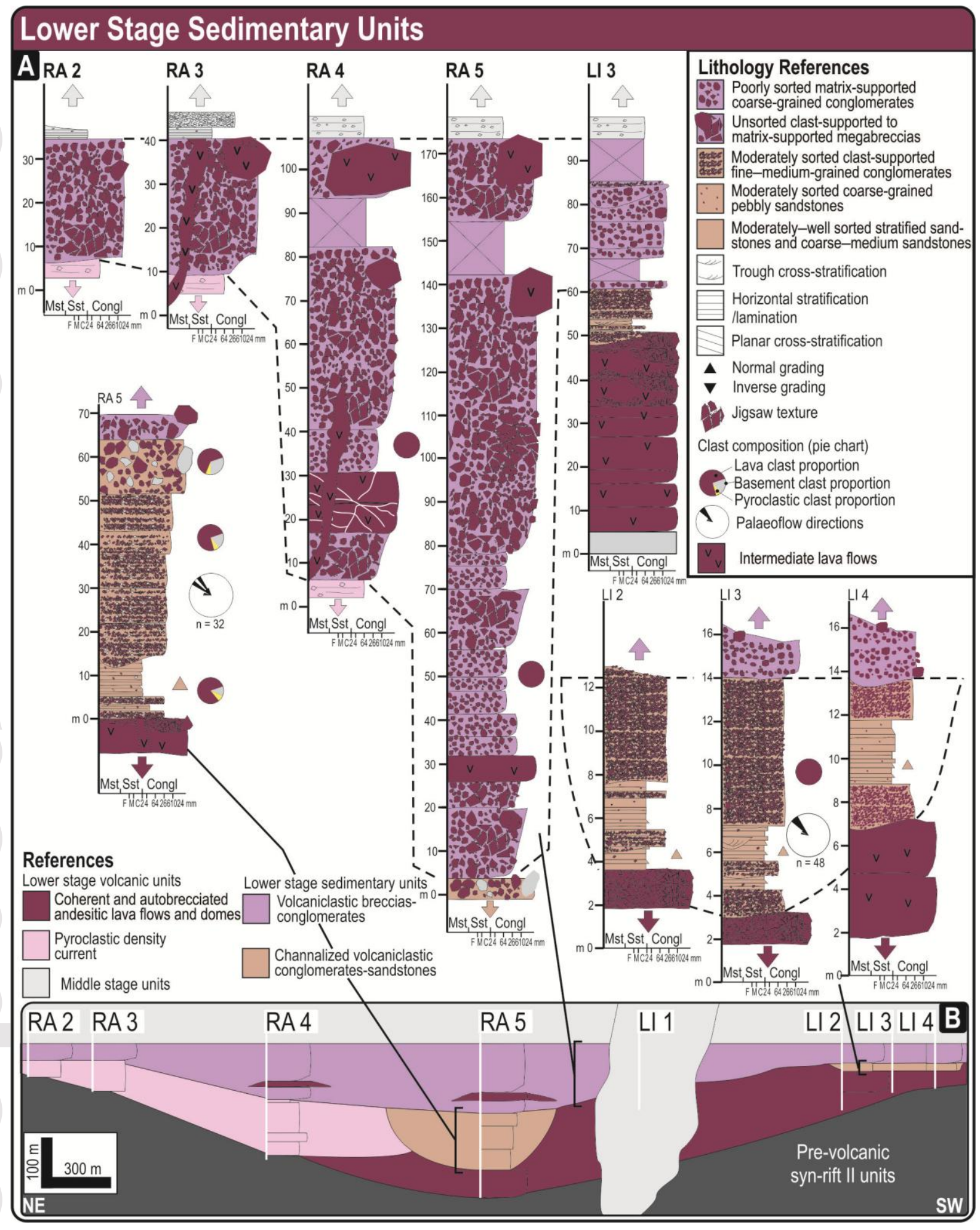

This article is protected by copyright. All rights reserved. 


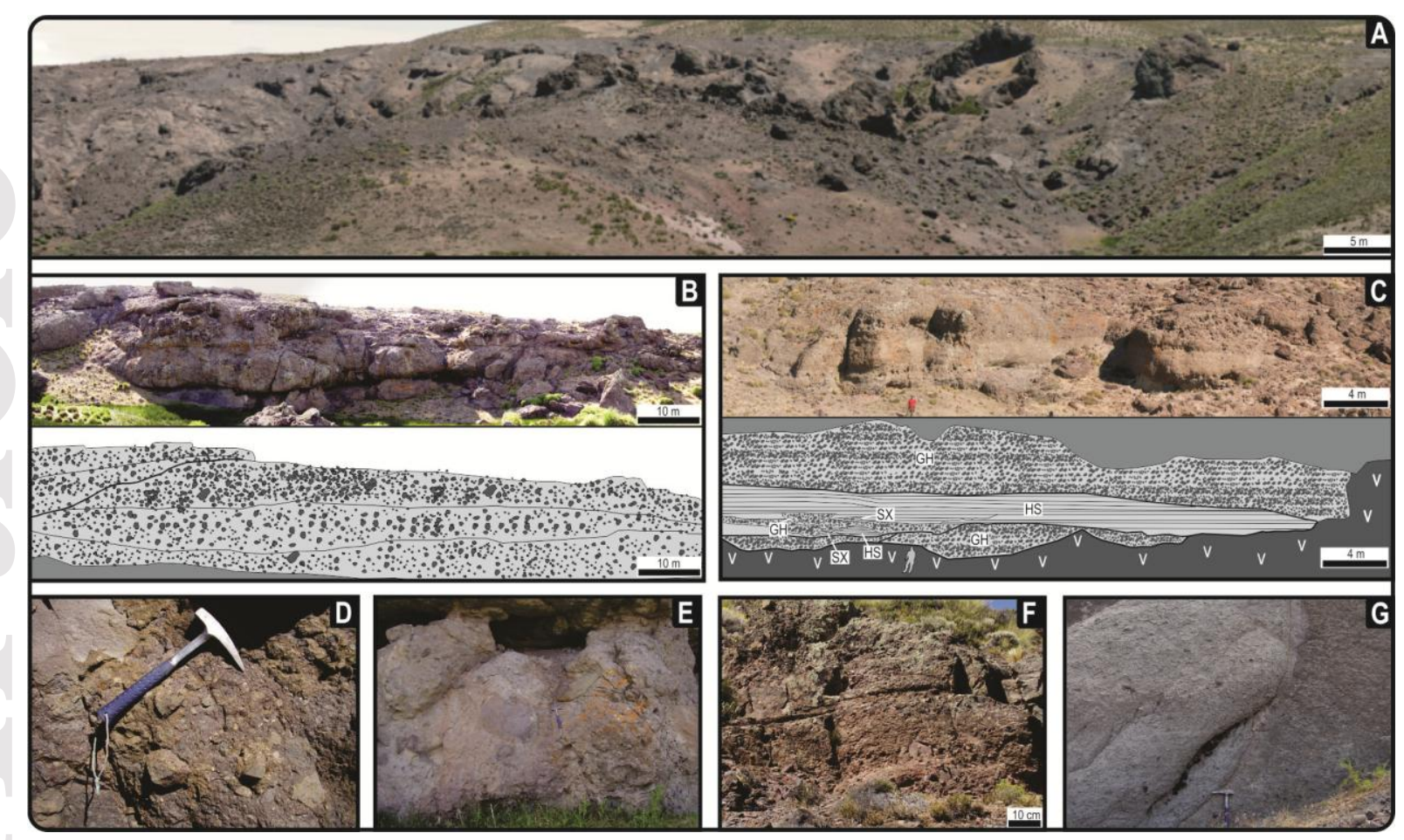

This article is protected by copyright. All rights reserved. 


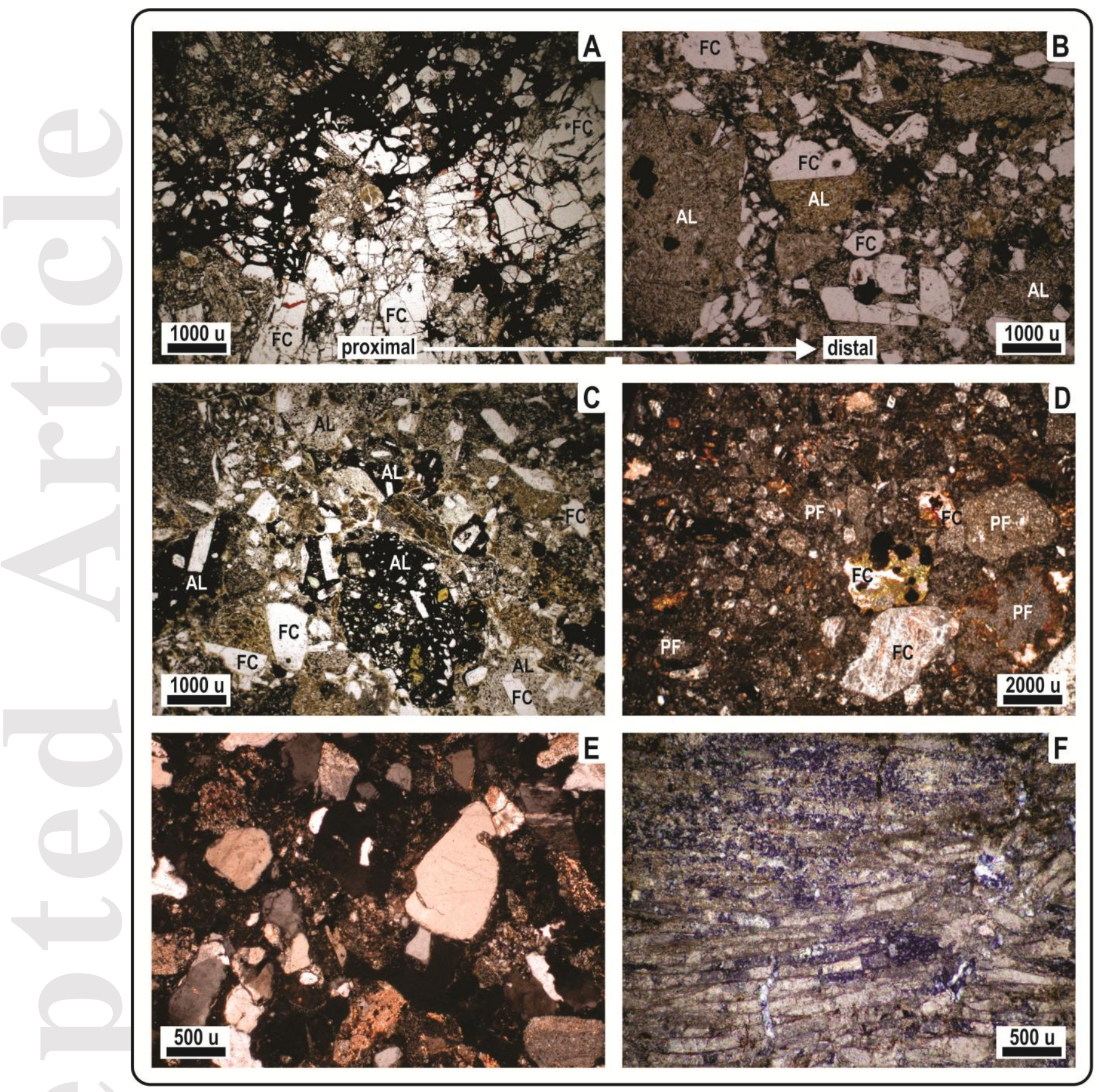

This article is protected by copyright. All rights reserved. 


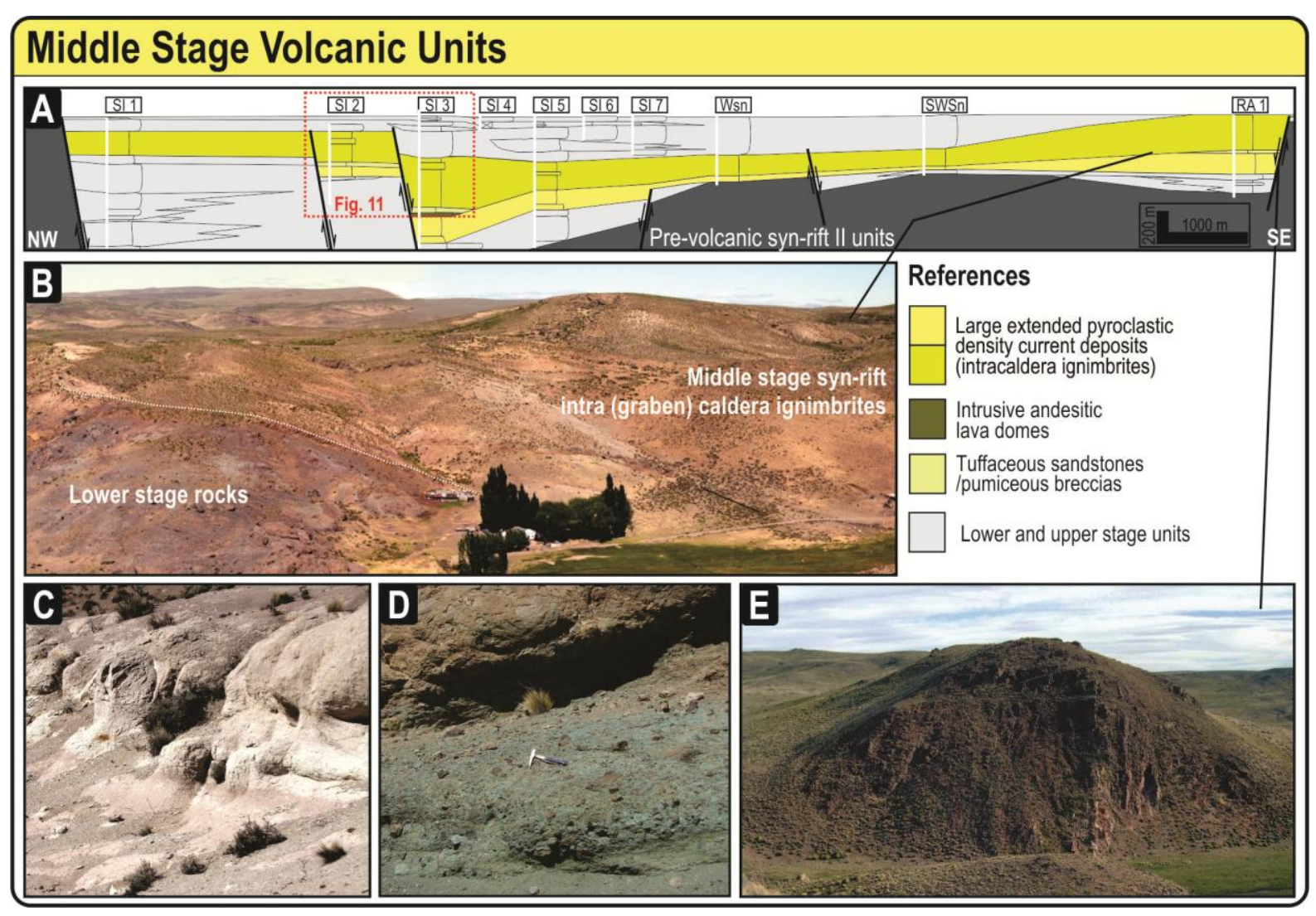

This article is protected by copyright. All rights reserved. 


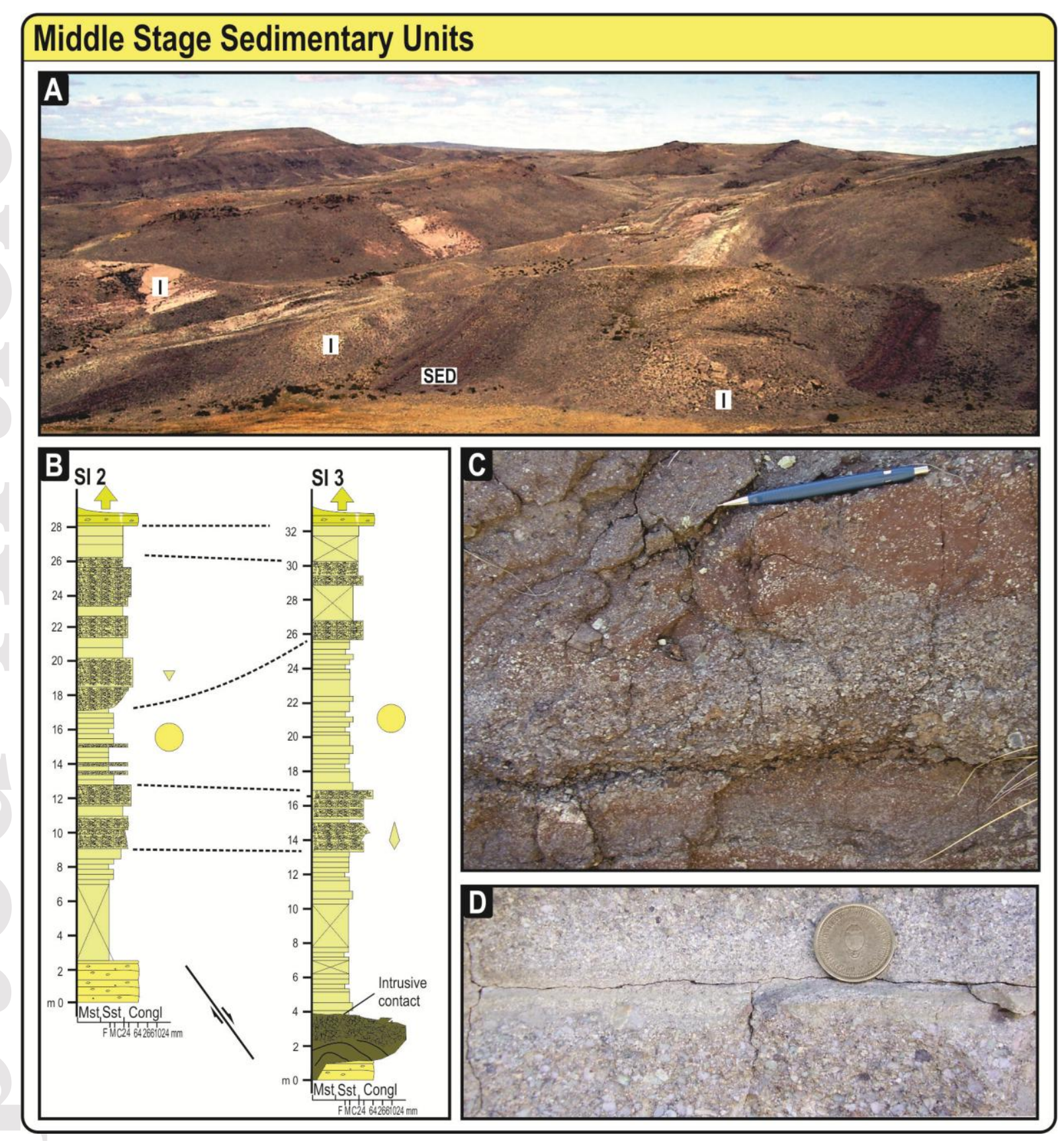

This article is protected by copyright. All rights reserved. 


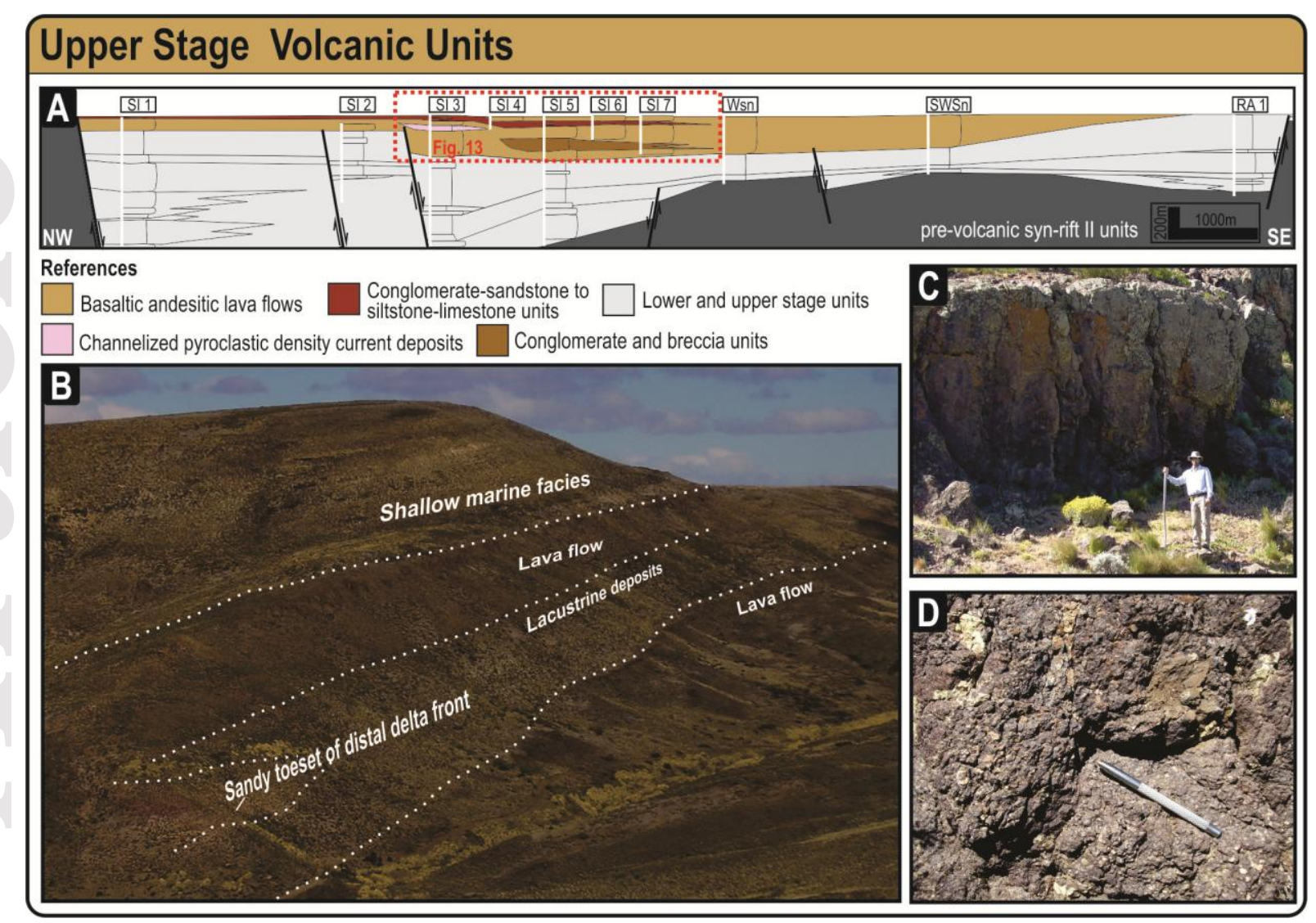

This article is protected by copyright. All rights reserved. 


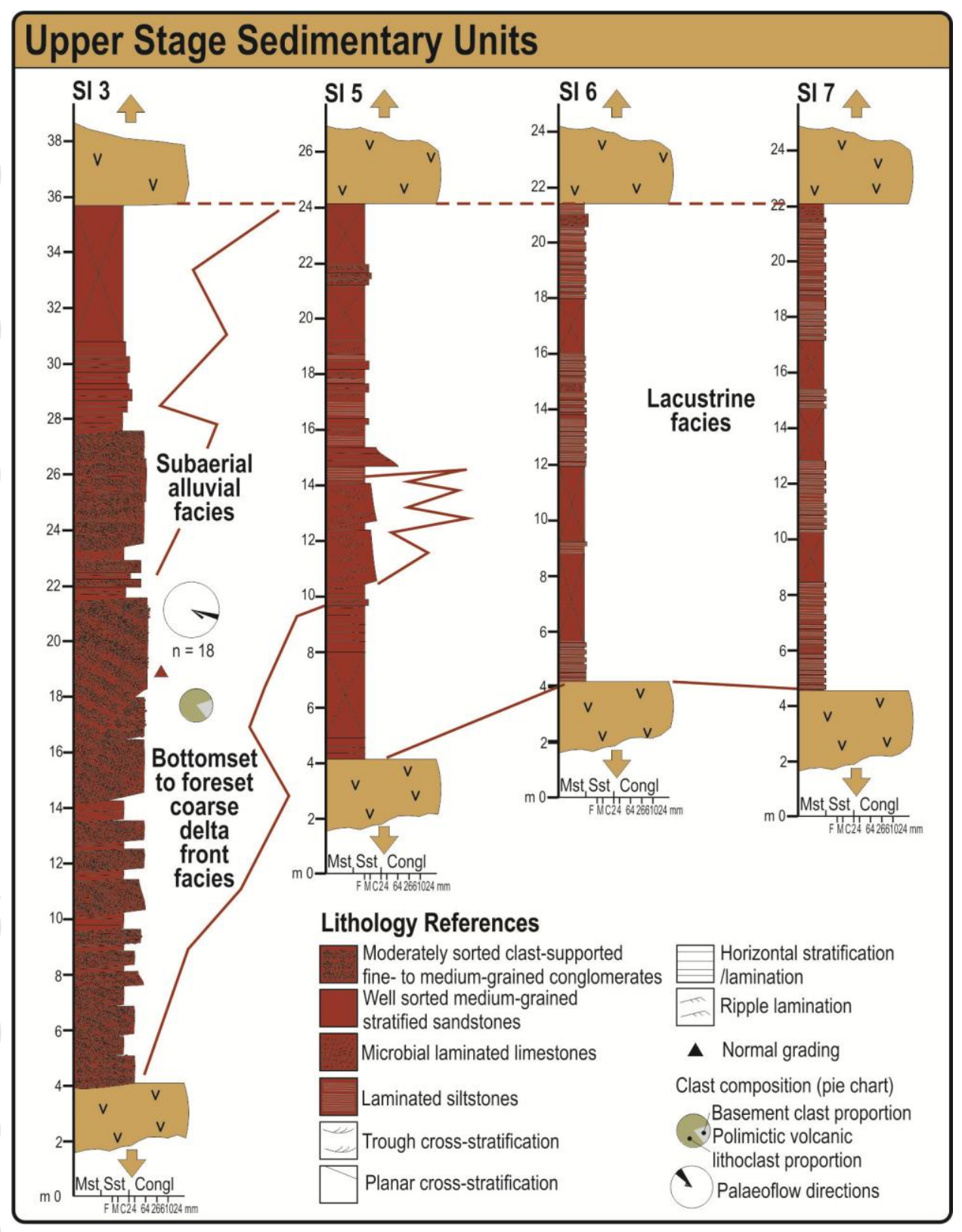

This article is protected by copyright. All rights reserved. 


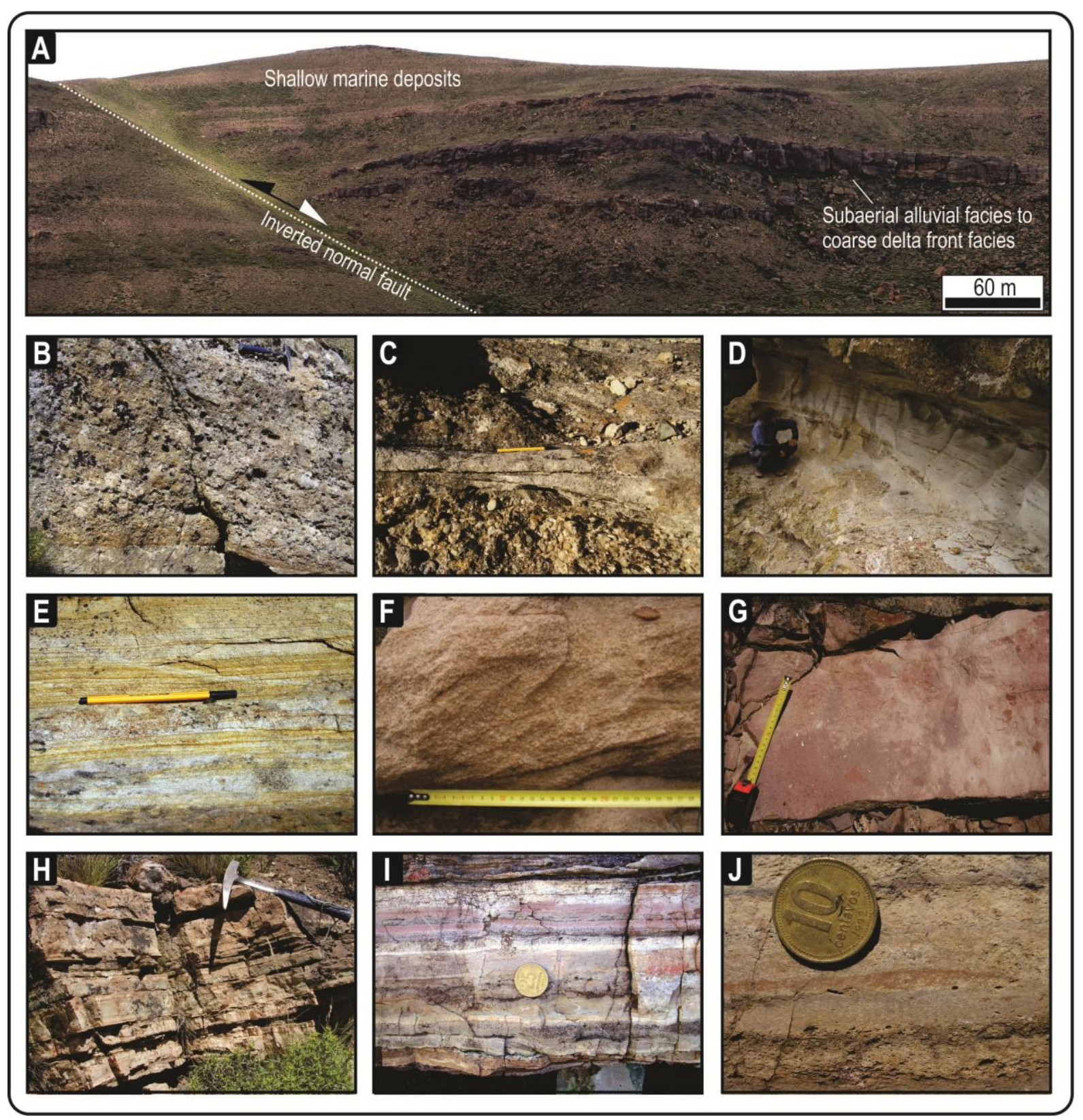

This article is protected by copyright. All rights reserved. 


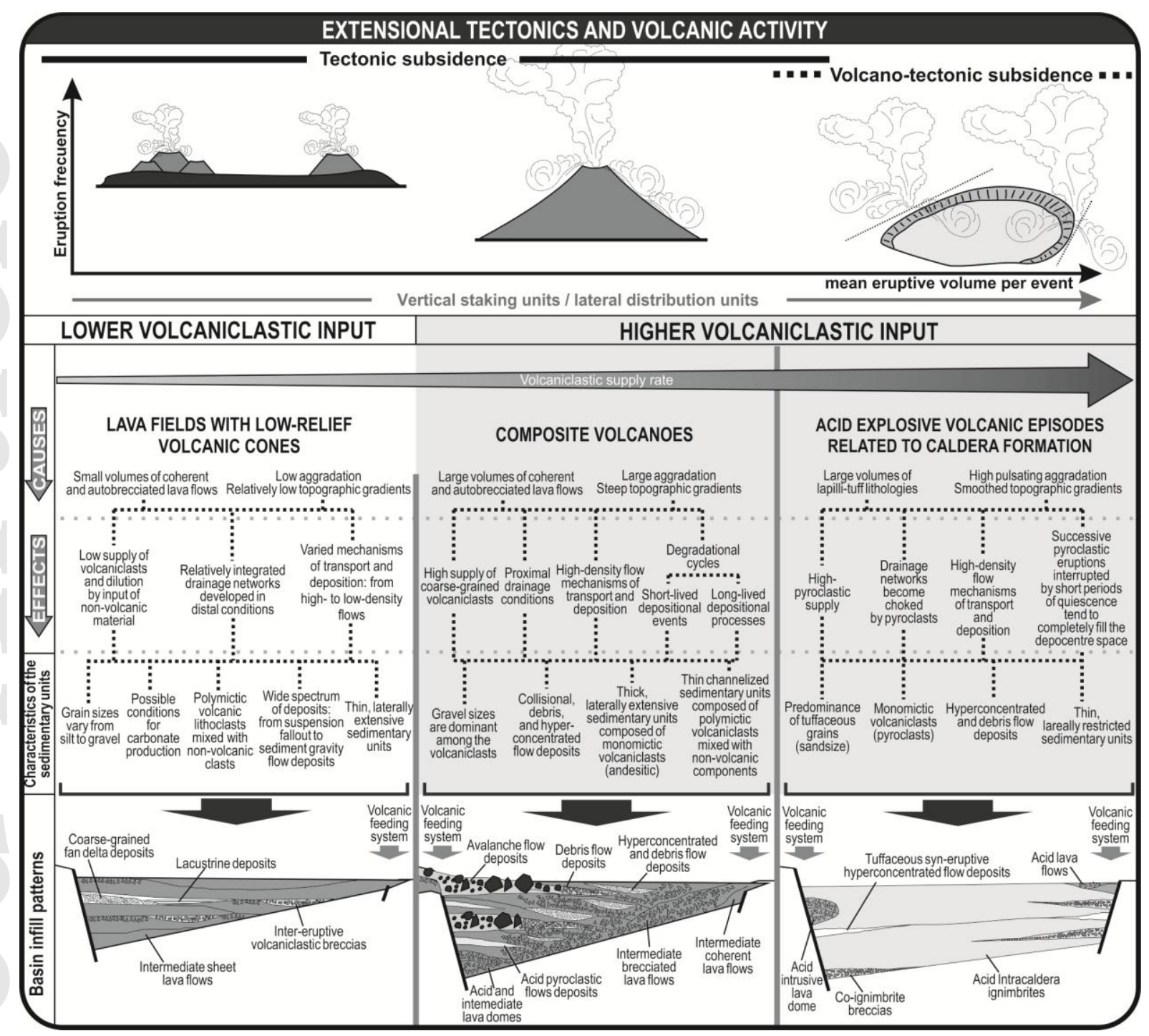

This article is protected by copyright. All rights reserved. 